\title{
Aspect and modality in Ewe: a survey
}

\author{
Felix K. Ameka
}

\begin{abstract}
This chapter provides a comprehensive description of the expression of aspect and modality in Ewe, a Gbe variety spoken in Ghana and Togo as far as and just across the Togo-Benin border. I strive to augment the existing descriptions of aspect and modality in Ewe and to present new analyses for some old phenomena. A fresh and systematic analysis of markers in the verbal cluster is presented (section 2). A striking relationship between the subjunctive, the third person imperative marker and a consecutive clause marker as manifest in Ewe is examined leading to new hypotheses about their heterosemic relations to the hypothetical conditional introducer and the marker of apodosis in counterfactual conditionals. Some of the Ewe empirical facts that bear on current concerns in linguistic theorising such as the relationship between the habitual and the progressive and whether imperatives in West African languages have overt subjects are addressed. An incipient grammaticalization of a proximative aspectual category is also documented. This chapter together with Essegbey's (this volume) on the potential, and the analysis of the imperfective aspect constructions in Ewe in the chapter by Ameka and Dakubu (this volume) constitutes a complete description of aspect and modality in Ewe.
\end{abstract}

\section{The non-prominence of tense in Ewe}

In Ewe, like in many other Kwa languages of West Africa, there is no overt marking of a grammatical category tense in the clause. The point in time at which a particular situation occurred is inferred from other material in the linguistic context. For example, from temporal nominals and adverbials, e.g., $t s \tilde{a}$ 'formerly', interpreted as having (remote) past time reference, or fifia 'now', interpreted as having present time reference. However, some spatial verbs could be interpreted as having a lexicalised time component. A locative verb suppletive set $l e \sim n \supset$ 'be.at' manifests a present/non-present contrast as illustrated below:
(1)
a. É-le
afé
3SG-be.at:PRES home
'S/he is at home' 


\section{b. É-no afé \\ 3SG-be.at:NPRES home \\ 'S/he was at home'}

Similarly, a pair of motion verbs $y i$ 'go' and $d e$ 'reach' have developed conventional interpretations where the former has a non-past orientation while the latter has a past interpretation. Compare the following:

(2)
a. É-yi afé
3SG-go home
'S/he has gone home'
b. É de afé
3SG-reach home
'S/he has been home' (i.e. S/he went and is no longer there)

In addition, the Potential marker can be interpreted as 'future' in context (see Essegbey this volume). Thus Ewe is not a tense-prominent language.

\section{Aspect and modality in the verb cluster}

Notions pertaining to aspect, mood and modality are expressed using various structures in Ewe. In the verb cluster, they are expressed by a verb suffix and a series of preverbal markers. In examples $(3 a, b)$ the verbs are marked by the habitual suffix. The linear order of the elements in a verb cluster is displayed in Table 1.

Table 1: Ewe verb complex

\begin{tabular}{|c|c|c|c|c|c|c|c|}
\hline \multicolumn{6}{|c|}{ Preverb markers } & \multicolumn{2}{|c|}{ Verb } \\
\hline Modal 1 & Aspect & $\begin{array}{l}\text { Directional } \\
1\end{array}$ & Modal 2 & Modal 3 & $\begin{array}{l}\text { Directional } \\
2\end{array}$ & & $\begin{array}{l}\text { Aspect } \\
\text { Suffix }\end{array}$ \\
\hline $\begin{array}{l}\text { Potential } \\
\text { (l) } a\end{array}$ & $\begin{array}{l}\text { Repetitive } \\
g a\end{array}$ & $\begin{array}{l}\text { Itive } \\
h e ́\end{array}$ & $\begin{array}{l}\text { Certainty } \\
\text { nyá }\end{array}$ & $\begin{array}{l}\text { Immediate } \\
\text { gbé }\end{array}$ & $\begin{array}{l}\text { Ventive } \\
\text { vá }\end{array}$ & Verb root & $\begin{array}{l}\text { Aorist } \\
\varnothing\end{array}$ \\
\hline $\begin{array}{l}\text { Subjunctive } \\
n a ́-\end{array}$ & & $\begin{array}{l}\text { Altrilocal } \\
d a\end{array}$ & $\begin{array}{l}\text { Voice } \\
\text { nyá }\end{array}$ & $\begin{array}{l}\text { Bother } \\
x a \\
\text { Etc. }\end{array}$ & & & $\begin{array}{l}\text { Habitual } \\
-(n) a\end{array}$ \\
\hline
\end{tabular}

There are various co-occurrence restrictions among the verb markers. The forms in column 1, the irrealis markers, are mutually exclusive with each other and also with the Habitual marker in the final column. A value of the realis/irrealis domain has to be expressed in each verbal clause in Ewe. As such these markers belong to the obligatory categories in the verb cluster and are 
discussed in section 2.1. Several of the preverb markers have developed from verbs and have a heterosemic relationship with the verbs. Anyone familiar with earlier descriptions of Ewe would immediately realise that the number of slots proposed here for the verb markers is different. One major difference is that the slot immediately preceding the verb word in previous works labelled the Augment by Ansre (1966) and later called Modal by Duthie (e.g. 1988, 1996) and others (e.g. Ameka 1991, Essegbey 1999, Ansre 2000:41) has been subdivided into four slots. This is meant to reflect not only the possible co-occurrence and sequencing of these forms, but also the heterogeneity within the Augment forms in terms of the categorial notions they encode.

Negation is a clausal operator with bipartite marking: $m e ́=$ occurs just before the verb cluster and $o$ occurs in the penultimate position in the clause before any clause final utterance particles (example $3 b$ ) but after any adverbials (example 3a). E.g.:
a. atsú-fé
$m e ́-n y e ́-a ́$
dzidzJ
husband-place NEG-COP-HAB happiness space always NEG
tefé dáá o
'Wifehood is not always full of happiness' (Fiawoo 1990 [1408])
b. nyatefé lá mé-tsrõ்-ná
$o$ hee
truth DEF NEG-perish-HAB NEG UFP
'The truth never perishes, I advise you' (Fiawoo 1990 [1509])

The $m e ́=$ part could be seen as a proclitic on the verb cluster and marking, where available, the beginning of the verb cluster, while the $o$ is an independent particle.

\subsection{Obligatory categories in the verb cluster}

\subsubsection{The Habitual}

A morphological defining feature of verbs in Ewe is that they can take a habitual suffix $-n a \sim a$. The Habitual suffix is a toneless morpheme which gets its tone value from the preceding syllable, that is, the last syllable of the verb stem. A prescriptive rule about the alternation between -na and $-a$ is that the full form -na occurs if there is no complement following the verb and $-a$ is used if there is a complement, as illustrated from the writing of one of the proponents of the prescriptive rule, Obianim (1990 [2153]):

$$
\begin{array}{llll}
E \text {-f5-ná } & y d i & y i-a & \text { agble } \\
\text { 3SG-rise-HAB morning } & \text { go-HAB farm } \\
\text { 'He gets up in the morning and goes to the farm' }
\end{array}
$$

Examples (3a, b) show that the Habitual can be used for generic statements and (4) shows that it also signals customary regular occurrences. The habitual 
implies a potential for the state of affairs to occur it does not therefore co-occur with the irrealis markers.

The habitual can have a motion-in-progress reading when it is used with two motion verbs: $y i$ 'go' and $g b s$ 'come back'. There is cross-linguistically an affinity between the progressive and the habitual which is evidenced in the interpretation of the habitual forms of these two verbs. However, all the cases that have been noted in the literature are situations in which the progressive marker in a language receives a habitual interpretation. This has been explained or accounted for in terms of the two categories being instances of imperfective aspect (e.g. Comrie 1976, Bertinetto et al. 2000).
a. Nye kplé da-nye yé yi-na núgbé éye 1SG LINK mother-1SG aFOC go-HAB journey and mie-dze adzodalá vṍdi et̃̃ sia-wó sí 1PL-contact robber evil three PROX-PL HAND me containing.region 'My mother and I were going on a journey and we fell into the hands of these three evil robbers.' (Obianinm 1990[650])
$\begin{array}{lll}\text { b. Dadá } & \text { gbo-na } & \text { dá } \\ \text { Mother } & \text { come.back-HAB } & \text { in.the.distance }\end{array}$ 'Mother is on the way coming back (do not cry).' (A children's rhyme)

The Ewe situation noted is one in which the interaction between a set of lexical items and the habitual yields 'motion in progress now' interpretation. Some analysts would rule out such an interpretation of the habitual since " $[\mathrm{I}] \mathrm{t}$ does not imply that an instance of the event is taking place "now" (Payne 1997:241). It remains to be seen whether such situations occur in other languages as well.

The behaviour of the habitual marker in Ewe differs in some respects from that of the habitual marker in the Eastern Gbe varieties such as Gungbe and Fongbe (cf. Aboh 1998, 2004 Lefebvre et al 2002). First, unlike the eastern Gbe forms which are preverbal markers and have the form $n$, the Ewe form is a suffix. Example (7) below, from Gungbe (Aboh 1998:61), shows the preverbal position of the habitual marker in one variety of Eastern Gbe. Second, Lefebvre et al (2002:95) report that $n \curvearrowright$ 'HAB' in Fon does not occur with individual level or stage level stative predicates like 'to know'. In Ewe all verbs can take the habitual including the equivalents of forms that do not co-occur with the habitual in the Eastern Gbe lects. For example, 
(6)

$$
\begin{aligned}
& \text { É-nyá-á nú yútś (Ewe) } \\
& \text { 3SG-know-HAB thing very } \\
& \text { 'S/He is very clever' }
\end{aligned}
$$

Kofi no sa agásá (Gun)

Kofi HAB sell crab

'Kofi habitually sells crab(s)'

\subsubsection{The irrealis markers}

The irrealis markers are incompatible with the Habitual. The Potential (see Essegbey this volume) is used to indicate the possibility of something happening. It has a non-high tone which may be realised in context as low. In some varieties it is realised as $l a$ and in many cases realised as $-a$-. It has been erroneously characterised as the future tense marker (e.g. Westermann 1930, Clements 1972; Duthie 1996), but it is better viewed as a modality or mood marker (cf. Ameka 1991). The Subjunctive, on the other hand, has an underlying High tone and the variants $n a ́$ and $a$. It is used to express wishes. As such it occurs in main clauses as well as the complement clauses of desiderative verbs and in other irrealis complements. Compare the following minimal pair which shows the differences in tonal realisation between the Potential and the Subjunctive and their interaction with the $1 \mathrm{SG}$ subject pronoun:

$$
\begin{aligned}
& \text { a. } M-\grave{a}-d e \quad w \grave{o} \\
& \text { 1SG-POT-remove 2SG } \\
& \text { 'I would marry you' i.e. It is possible that I will marry you' } \\
& \text { b. } M \text {-á-de wò } \\
& \text { 1SG-SUBJV-remove 2SG } \\
& \text { 'I should marry you' i.e. I want to marry you' }{ }^{1}
\end{aligned}
$$

In some contexts, such as after a low tone pronoun, the surface distinction between the Potential and the Subjunctive is neutralised, especially when expounded by the onsetless form $-a$ - For this reason I have sometimes glossed such forms as just Irrealis.

In sum, a Verb + Habitual structure means roughly 'situation happens (every time)'; the Potential + Verb form means roughly 'situation can happen' and Subjunctive + Verb from means 'someone wants situation to happen'.

\subsubsection{The aorist}

A verb that is not marked for the Habitual nor accompanied by one of the irrealis markers can be considered a bare verb that is in the aorist. Another way of viewing this is to say that the habitual and the irrealis are in opposition to the aorist. The aorist form indicates that the state of affairs encoded in the verb oc- 
curred at a time prior to the reference time. Hence in the case of inchoative verbs the post-state is interpreted as having present time reference while dynamic and action verbs have a past time interpretation. Compare:
a. Me-lĩ
wò kplé dzi
1SG-come.to.love 2SG COMheart
'I love you with my heart' (A line from a popular song)
b. Kofi fo devíá
NAME strike child-DEF
'Kofi hit the child (before now)'

Welmers (1973:346-7) suggests the term 'factative' for this form of the verb. He writes:
"A better label might be "factative"; the construction expresses the most obvi- ous fact about the verb in question, which in the case of active verbs is that the action was observed or took place, but for stative verbs is that the situation ob- tains at present".

What is referred to as stative here can be read with respect to Ewe as inchoative since there are only these two types of verbs: action and inchoative (cf. Essegbey 1999). Thus a bare verb form just says roughly speaking 'Verb happened before now'.

To sum up so far, in Ewe a verb cluster must obligatorily be marked for the habitual, or the irrealis or it should be the non-overtly expressed factative. Each of these morphological markers can be viewed as selecting a value on the scale from irrealis to realis where the most realis is the factative followed by the habitual which is less of a realis than the factative and then the irrealis markers which are more irrealis than the habitual. The categories are mutually exclusive with each other.

What I am suggesting here is that a verbal clause in Ewe has to expound one of the grammatical categories in Fig 1. That is to say that the language forces its speakers to select a value for the realis/irrealis for every verb in a clause. This is comparable in a way to the requirement in Russian for example where every verb has to be marked for either perfective or imperfective aspect (cf. Apresjan 2000). In terms of the features of the Ga verb presented by Dakubu (this volume) it would appear that a similar choice for the realis category is operative in Ga grammar. What seems to be different is that in Ewe in terms of the linguistic marking, the realis/irrealis feature has four values as opposed to two for Ga. 
Figure 1: Obligatory categories of the Ewe verb on a realis continuum

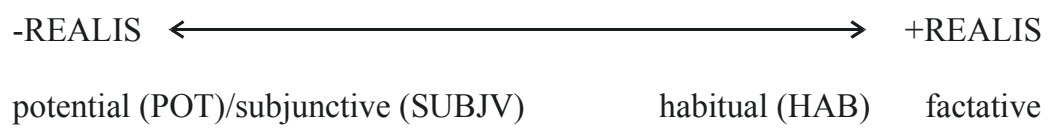

The central role of the Habitual in Ewe can speak to some of the debates in the typological literature on this category. One of the disputes concerns whether it is a tense, mood or aspect category (Bhat 1999). The aspectual character of the Habitual in Ewe, I believe, is not in doubt. However in context it has some mood and temporal or tense features. I have shown above that in combination with certain verbs it has a present progressive interpretation, which means that it encodes a meaning of the kind 'the motion happens now'. In this usage it has affinities with both tense and aspect categories. Similarly, I have demonstrated that the habitual is mutually exclusive with the irrealis markers. I suggested that this may be because of the meaning component of possibility: something can happen. If this is true then the habitual connotes a mood feature. In any case the obligatory marking of a realis/irrealis value whose exponents are either aspectual or modal suggests that Ewe is an aspect/modality prominent language and not a tense prominent language (cf. Bhat 1999).

\subsection{The non-obligatory preverb markers}

The grammar requires the choice of the realis or irrealis markers in each verbal clause. The use of the other preverb markers shown in Table 1 depends on the choice of the speaker and the meaning they want to convey. The forms, functions and meanings of these preverb markers are outlined below.

\subsubsection{The repetitive}

The Repetitive marker is $g a$. It can co-occur with any of the other elements in the verbal cluster. It is used to indicate the repetition or iteration of a state of affairs or the restitution of a state of affairs to its former state (cf. 10b). It can thus be interpreted as 'again'. The repetitive sense of the ga morpheme may be reinforced by an adverbial intensifier áké which may be optionally added to a sentence in which it occurs, e.g.: 

(10) a. Me-ga-vá yi áké
1SG-REP-come go again
'I have passed again'
b. ékemá súbólá-wó ga-kó-ne yi-a nú.qu.xo.me then servant-PL REP-carry-HAB:3SG go-HAB dining-room 'Then the servants carry him back to the dining room' (Obianim 1990 [81])

The repetitive can also be interpreted as a persistive, in which case it translates as 'still' in English. The persistive interpretation could also be reinforced by the intensifier ko 'just, only' or its triplicated counterpart kokooko 'just, only'. The persistive reading derives from the interaction of the repetitive marker and a factative verb that has present interpretation. Consider the following example:

$$
\begin{aligned}
& \text { égbe lá, é-fé ýkó ga-li kokooko } \\
& \text { today TP 3SG-POSS name REP-be.at:3SG TRIP:just } \\
& \text { 'Today, his name still exists' (Obianim } 1990 \text { [51]) }
\end{aligned}
$$

When it co-occurs with the negative, it translates as 'no longer, any more'. It is used in combination with the imperative and the negative to express prohibitions (see below). Together with the verb wu' 'surpass, exceed' it has formed a discourse connective gawú 'furthermore, moreover'.

\subsubsection{The directional preverbs}

The directional preverbs $h e$ 'ITIVE' and $d a$ 'ALTRILOCAL' have been analysed as serial connectives (Ansre 1966; Ameka 1991) and as verbal coordinators (Dzameshie 1998). These analyses are influenced by the fact that the directionals are frequently used in multiverb constructions. They are analysed here as directional preverbs on the basis of their syntagmatic distribution. They occur typically after the irrealis markers, and after the repetitive marker. In some contexts they can precede the repetitive marker. They can occur in the same slot as $v a ́$ 'VENT' when they occur in an SVC as in (12):

$$
\begin{aligned}
& \text { (12) a. É-yi asi.me héfle avo } \\
& \text { 3SG-go market IT buy cloth } \\
& \text { b. E-yi asi.me da fle avo } \\
& \text { 3SG-go market ALTRI buy cloth } \\
& \text { c. É-yi asi.me vá fle avo } \\
& \text { 3SG-go market VENT buy cloth } \\
& \text { 'S/he went to the market and bought (a piece of) cloth' }
\end{aligned}
$$


It seems counterintuitive to give a different analysis to forms that occur in the same paradigmatic slot and since nobody ever analyses $v a$ 'VENT' as a connective, I think it is better not to analyse the directionals also as such. The form hé 'ITIVE' must have evolved from the verb hé 'go away, disappear'. It is used to indicate the simultaneity or sequential in time of the state of affairs characterised in the verb relative to the rest of the discourse. For instance in (12a) above, the buying of the cloth was subsequent to the going to the market.

The form da 'ALTRILOCAL', which Westermann (1930:133) surmises also evolved from a motion verb, but whose verbal counterpart is lost in the present day language, is used to indicate that the state of affairs characterised in the verb occurred in a place different from the deictic centre. Thus in (12b) above, the buying of the cloth occurred in a place different from the deictic centre. The two directionals can co-occur and they can co-occur with other preverb elements so long as the combinations make sense. These forms are similar to the Ventive vá (see section 2.2.5) in having a spatial motion flavour, and all three are similar to the forms called the GRESSIVEs in Dangme (Dakubu this volume) and Akan (Boadi this volume). Osam (2002) proposes to analyse the Akan forms as Directionals. The use of the label Directional for the ITIVE and the ALTRILOCAL forms is inspired in part by this suggestion. Consider the following example:

$$
\begin{array}{llll}
\text { ési } \begin{array}{c}
\text { ò-hé-da-nyá } \\
\text { when }
\end{array} \text { 3SG-IT-ALTRI-CERT MODVENT } & \text { dó } & k o-a \\
\text { arrive } & \text { only-TP } \\
\text { 'as soon as he eventually did arrive ... } & &
\end{array}
$$

\subsubsection{The nyá modals}

The two nyá modals-one for epistemic certainty and the other for marking Undergoer Voice- bear a heterosemic relation to the verb nyá 'come.to.know'. The two modals are mutually exclusive. However they can each co-occur with the main verb form nyá 'come.to.know' as in:

$$
\begin{aligned}
& \text { E-nyá nyá tsi-fü-fü } \\
& \text { 3SG-CERT know water-RED-move.limbs } \\
& \text { 'S/he does know how to swim' }
\end{aligned}
$$

$$
\begin{aligned}
& \text { é-dó vivití; mé-nyá nyá-ná o } \\
& \text { 3SG-put.on darkness 3SG:NEG-VOICE know-HABNEG }
\end{aligned}
$$

'[A person's interior is like the barrel of a gun] It is dark; it is not knowable' (i.e. one cannot know it) (Ayeke 1974 [2251])

There is a formal difference between the two nyá modals as well: The epistemic certainty nyá modal can occur in one, two or three place constructions (see 14 above where it occurs in a two place construction). The Voice modal 
marker, on the other hand, participates in a one-place construction in which the single argument is an Undergoer as in (15). An effector-experiencer argument can be expressed as a dative object. Because of this it has been said that such nyá constructions are syntactically like passives (Essegbey 1999, Collins 1993, Duthie 1996). The semantics of the construction is not an agent passive one. Rather it is more like that of a facilitative or potential or capability passive.

The two nyá modals seem to form a paradigmatic set that is why they are placed in a slot by themselves. The epistemic certainty marker can co-occur freely with other modals and tends to precede them. However, it can also occur after some members of the second modal class such as gbé 'just'. The voice marker, however, does not easily collocate with other modal markers (see the next section).

\subsubsection{The other modals}

As indicated above, the epistemic certainty marker can collocate freely with the other modals. One of the modals that enters into construction with it is gbé 'just', as we have seen. It is hard to say what the origin of this gbé 'just' form is. Example (13) illustrates its use with other preverbs. In the rest of this subsection the form, meaning and use of the other preverb modals are described.

(a) The counter-expectation marker kpó. This marker, grammaticalized from the verb kpś 'see' in a serial verb construction (cf. Heine et al 1991:199202), is used to indicate that one would have expected the state of affairs encoded in the verbal clause should have occurred by the reference time, but this is not the case. It always occurs in a negative clause. For this reason, I think, Ansre (1966) called it the negative augment. Westermann (1930:138) characterises it in the following way: "The verb kps' 'to see' is often immediately followed by a second verb and then means: "to have opportunity, time"". From this, it can be inferred that its equivalents in other languages may be the 'not yet' tense or aspect forms. To emphasise the 'not yet' sense, it tends to collocate with the adverbial hadé 'yet'. Consider the following examples which show that the subject in such clauses can be abstract or animate, it is a speaker's judgement or expectations that matter.

(16) a. susú sia mé-kpó gé dé wó-fé ta.meháfi ... thought PROX NEG-CE drop ALL 3PL-POSS head before 'This idea hardly got into their heads before [they ran home]' (Gadzekpo 1982:11)

b. Ameewú mé-kpó tsi xo fe bláeve g̃ hỗ... NAME NEG-CE grow get year twenty even also ... 'Ameewu was not yet even twenty [before the parents were tired of the suitors]' (Dogoe 1964: 9) 
(b) The ability and possibility marker té yú. Ability and possibility are expressed by the verb noun collocation té yú 'press body'. As a preverb modal expression, the form té does not take the Habitual marking for verbs. When it occurs with the Habitual then it is unambiguously a verb. In many other cases, it functions as a modal. In the example below the form té may be marked for the Habitual in which case the utterance is a serial verb construction (SVC) or it may not, in which case the utterance is a monoverbal clause with a preverb modal of ability.

$$
\begin{array}{llll}
\text { deví-á } & \text { mé-té(-á) } \quad \boldsymbol{y} \boldsymbol{u} & d u-a & n \dot{u} \quad o \\
\text { child-DEF } & \text { NEG-press-HAB BODY eat-HAB } & \text { thing NEG } \\
\text { 'The child is not able to eat (customarily)' } &
\end{array}
$$

Some speakers tend to create a distinction between the verb form and the preverb modal form. Such speakers compound the predicate and the nominal constituents and then delete the final vowel leaving the velar nasal as a syllabic segment. It should not be long before one can definitively say the verb form is té $y u$ ' press body' and the modal form is téý 'CAN'.

(c) The DARE modal katse. The form katse 'dare' seems to have developed as a single word from the verb noun collocation $k e$ 'open (body part) and atse 'jaw'. This form does not function as a verb but only as a preverb. It is used to challenge and dare someone to do something. For example,

$$
\begin{aligned}
& \text { né è-katse de así le ame sia yú lá... } \\
& \text { if 2SG-DARE remove hand LOC person PROX POSTP TP } \\
& \text { 'If you dare release this person ....' }
\end{aligned}
$$

(d) The IN VAIN marker xa. The preverb marker $x a$ 'in vain, bother' is used to express a frustrative meaning. It is probably related to the verb $x a$ 'suffer'. The grammaticalization of this form as a preverb marker is still in progress and is evident from the fact that the complement of the main verb can intervene between the preverb marker and the main verb or come after the main verb. Compare the following sentences which are by and large synonymous:

$$
\begin{aligned}
& \text { a. me-xa vá afé } \\
& \text { 1SG-bother come home } \\
& \text { 'I came home in vain' } \\
& \text { b. me-xa afé vá } \\
& \text { 1SG-bother home come } \\
& \text { 'I home-came in vain' literally }
\end{aligned}
$$

It can be argued that in the cases where the $x a$ form is not immediately followed by a verb as in (19b) the form is still a verb and the $x a$ Object V structures are instances of SVCs with shared objects. 
(e) The marker ká 'different from the norm'. The marker ká 'a little different from the norm' is a modal that probably grammaticalized from the verb $k a$ ' 'break off'. In context, $k a ́$ as a modal can be interpreted as a little less, as in (20), or a little more than the expected norm. The norm in this case is the state of affairs denoted by the verb and its complements.

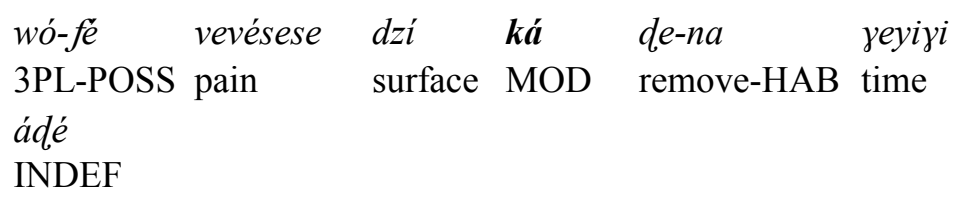

'Their suffering reduces a little bit for some time' (Obianim 1990 [1966])

\subsubsection{The Ventive vá}

The ventive $v a$ preverb is used to express the idea of a state of affairs eventually happening. It is in a heterosemic relation with the verb vá 'come'. Both forms can co-occur. It is assigned to the slot immediately before the verb because it tends to be the last of the preverb markers if more than one of them occurs. Thus even though it is a directional and can be in paradigmatic opposition to the other directionals we saw in section 2.2.2, when it cooccurs with them it always comes after them. This is the reason it is treated separately here. (For a full discussion of the differences between the auxiliary and the main verb forms of $v a$ 'COME' see Essegbey 2004).

$$
\begin{aligned}
& \begin{array}{llll}
E \text { E-vá } & v a ́ & \text { é-me } & \text { béná ... } \\
\text { 3SG-VENT } & \text { come } & \text { 3SG-containing.region COMP }
\end{array} \\
& \text { 'It came to pass that ...' }
\end{aligned}
$$

Thus far the markers on the verb and the categories and meanings that they express have been surveyed. We have seen that there are four obligatory values of the realis/irrealis continuum one of which must be selected in every clause in the clause. We have also seen the full range of markers of different kinds of modality or quantificational, i.e., repetitive, aspect that occur as preverbs on the verb. In the subsequent sections we will examine other markers and constructions that pertain to aspect and modality but which do not occur within the verb cluster. The rest of the discussion begins with modality-related forms- periphrastic modal constructions, utterance final particles and imperative constructions. This is followed by a discussion of the aspect-related structures beginning with adverbial particles and concludes with periphrastic aspectual constructions, namely the phasal aspect constructions and the proximative. 


\section{$3 \quad$ Periphrastic modal constructions}

Modality meanings of obligation, necessity and evaluation are expressed in structures that can schematically be represented as $\boldsymbol{E}^{-}$'3SG Expletive' Verb bé 'COMP' clause.

The construction is made up of the expletive (or cataphoric) 3SG pronoun as subject followed by a verb (chosen from a semantic class) followed by the quotative or complement clause introducer bé followed by a clause expressing the proposition that must happen or is being evaluated. Necessity and obligation meanings are expressed using le (vévié) 'be.at:PRES (important)', $d z e$ 'be fitting' and hiá 'need' as matrix verbs in these structures.
a. $\quad$-le
bé
lã-wó ná-du
fia vṍdi sia
3SG-be.at:PRES COMP animal-PLSUBJV-eat chief bad PROX
'Beasts must devour this evil chief' (Bidi Setsoafia 1989:16)
b. é-dze bé nà-vá kpó-m
3SG-fit COMP 2SG:SUBJV-VENT see-1SG
'You must come to see me'

As is evident from the examples, the complements of these verbal expressions are irrealis complements with the verb marked for the subjunctive.

Emotional and attitudinal predicates such as nyó 'become.good' sé 'become.hard /strong', so 'be.equal' vivi' 'be sweet, tasty' and the transitive verb $v e$ 'be painful' are used in a closely related construction to express evaluative modality. With these predicates, an Experiencer can be added and coded as a dative prepositional object as in (23b) or a direct object, or as the dependent NP in a postpositional NP (see Ameka 1990a). Unlike the necessity and obligation structures, the complement clauses of the evaluative predicates need not be in the irrealis (see 23a).
a. é-nyó bé mi katã́ mie-fo fü dé afi sia 3SG-good COMP 1PL all 1PL-hit bone ALL place PROX 'It is good that we all have gathered here'

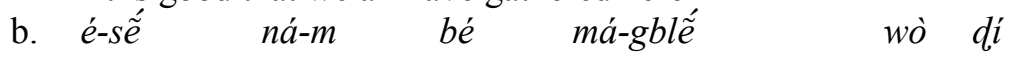 3SG-hard DAT-1SG COMP 1SG:SUBJV-spoil 2SG down 'It is hard for me to abandon you'




\section{Utterance particles}

Apart from the preverbal markers, some meanings that relate to mood and modality are expressed by items that operate at the clause or utterance level. Propositional and speaker attitudes are expressed by a set of utterance particles displayed in Table 2 below (see Ameka 1986, 1998 for a description of these particles). In brief, Ewe utterance particles are a closed class of little words that occur as the outermost peripheral elements of utterances, be they words, phrases, clauses or sentences, grammatically speaking. They are used to signal, attenuate or boost the illocutionary forces of the utterances in which they occur. Thus they convey various attitudes of the speaker towards what is being communicated, i.e. the propositional content, or towards the elements in the communicative context such as towards the addressee or towards other observers (Ansre 1966, Duthie 1996:51). From this point of view they are expressions of modality. They can be classified according to their position in the utterance as either utterance-initial or utterance-final as shown in Table 2. They can also

Table 2: Ewe utterance particles

\begin{tabular}{|c|c|c|}
\hline Function & Utterance initial & Utterance final \\
\hline QUESTION & $\begin{array}{l}\text { děe 'emphatic question introdu- } \\
\text { cer' }\end{array}$ & $\begin{array}{l}\text { à 'ignorative marker' } \\
\text { dé 'topic-only question marker' } \\
\text { lóo 'alternative question marker' }\end{array}$ \\
\hline $\begin{array}{l}\text { ADDRESSIVE/ } \\
\text { ATTITUDINAL }\end{array}$ & $\hat{o}$ 'vocative initial particle' & $\begin{array}{l}\text { à 'ignorative marker' } \\
\text { dé 'agreement seeking marker' } \\
\text { là 'urgent imperative' } \\
\text { ló 'I advise you' } \\
\text { hee 'I advise you' } \\
\text { lóò 'I am surprised!' } \\
\text { lòò 'pay attention to what I say' } \\
\text { sèà 'you hear' } \\
\text { tò̀ 'dear, endearment' } \\
\text { gòò 'I feel good towards you' } \\
\text { (l)ée 'hailing particle' } \\
\text { òo 'vocative final particle' }\end{array}$ \\
\hline
\end{tabular}

be classified according to their function or the clause type in which they occur. Those that have a question function are mutually exclusive with those that have an attitudinal marking function. 
Consider the uses of two of the particles in the following question and answer pair:

$$
\begin{aligned}
& \text { GB } \grave{E}-s e \quad g b e \text { lá máhã-a } \\
& \text { 2SG-hear voice DEF at.all-UFP } \\
& \text { 'Have you heard the message at all?' } \\
& \text { EG Me-se-e tos, tógbúi-nye } \\
& \text { 1SG-hear-3SG UFP grandpa-1SG } \\
& \text { 'I have heard it, my dear grandpa.' (Fiawoo } 1990 \text { [1612-13]) }
\end{aligned}
$$

Since some of the particles, such as the ignorative $a$ 'I don't know something about this', can be used with different sentence types-declarative, imperative and interrogative-it can be assumed that they do not specifically encode these moods. Rather they modify the illocutionary force of utterances. Compare the following near minimal pairs:

$$
\begin{array}{ll}
\text { (25) a. } & \text { devi-á } f 5 \\
& \text { child-DEF rise } \\
& \text { 'The child got up.' } \\
\text { b. } & \text { devi-á f5- } a \\
& \text { child-DEF rise-UFP } \\
& \text { 'Did the child get up?' } \\
\text { c. } & \text { f- } a \\
& \text { 2SG:rise-UFP } \\
& \text { 'Why don't you get up?' }
\end{array}
$$

The sentences show that when the ignorative is added to an otherwise declarative statement it adds the force of a propositional question. When it is added to an otherwise imperative utterance it signals the speaker's exasperated criticism of the addressee's negligence in carrying out the state of affairs represented in the clause. It has been speculated in the literature that markers of interrogativity should not occur with explicit imperatives (cf. Chisholm et al eds 1983). If the analysis proposed here for Ewe is correct, then the ignorative utterance final particle provides counter evidence to such a claim.

\section{Imperative constructions}

\subsection{The second person imperative}

The second person imperative has the form Subject [2 ${ }^{\text {nd }}$ Person] Verb X. The verb is not modified by any markers of the verbal complex. The illocutionary point of the construction is 'I want you to do something'. If the subject is instantiated as a $2 \mathrm{SG}$, it is only realised tonally as Low. The effect of the low 
tone is evident when the verb is inherently high and its initial consonant (or onset) is a voiced obstruent; the low tone is linked to the high to yield a rising tone (cf. Ansre 1961, Duthie 1996). The rising tone may be realised as mid tone in some dialects and contexts. In (25c) above, an instantiation of a singular imperative construction, the tone on the verb is high because the initial consonant ' $\mathrm{f}$ ' is a voiceless obstruent. Compare that with the form in (26a) below. ${ }^{2}$

$$
\begin{aligned}
& \text { a. vă afi } \\
& \text { 2SG:come here } \\
& \text { 'Come here.' } \\
& \text { b. dzó vá afi } \\
& \text { 2SG:leave come here } \\
& \text { 'Leave (and) come here.' } \\
& \text { c. mi-vá afi } \\
& \text { 2PL-come here } \\
& \text { 'You (PL) come here.' }
\end{aligned}
$$

In (26a) the tone of $2 \mathrm{SG}$ is evident in the rising tone of the verb vă 'come'. In (26b) however, there is no manifestation of a 2SG subject on the same verb $v a$ in the imperative when it occurs as the second verb phrase in a serial verb construction (SVC). This is because the subject is expressed only once in an SVC. The first verb in the imperative SVC in (26b) has rising tone because the initial consonant is a voiced obstruent and the verb stem tone is high (cf. Ameka 2006).

As is evident from (26c) above, a second person plural imperative construction is minimally made up of a $2 \mathrm{PL}$ pronoun followed by the verb phrase. The subject pronoun is obligatory. In fact, the plural structure in (26c) is ambiguous between an imperative reading and a declarative reading, namely '(You) come here!' vs. 'You came here.' The source of the ambiguity is in the form of the pronoun which is the second person plural pronoun. However, the two readings could be disambiguated: the imperative form will always have the short pronoun form $m i$ ' $2 \mathrm{PL}$ 'whereas the non-imperative forms can take the longer form mie '2PL'. Compare the following forms:

$$
\begin{aligned}
& \text { a. mi-vá afi } \\
& \text { 2PL-come here } \\
& \text { 'You (PL) come here.'/ 'You (PL) came here.' } \\
& \text { b. mie-vá afi } \\
& \text { 2PL-come here } \\
& \text { 'You (PL) came here.' } \\
& \text { c. mia-vá a afi } \\
& \text { 2PL:POT-come here } \\
& \text { 'You (PL) would come here.' }
\end{aligned}
$$


A similar indeterminacy has been observed for Fongbe (Lefebvre and Brousseau 2002:110).

The imperatives can also be preceded by vocative or topic phrases distinct from the subject pronouns in the imperative construction, as in the following excerpts from the famous advisory speech of Togbe Sri, a revered Anlo chief:
a. Vi-nye-wó mi-ga-ylo-e bé $o \ldots$ child-1SG-PL 2PL-REP-forget-3SG VS NEG 'My children, do not forget ...'
b. Mi deví-wó lá mi-dó tó mia dzilá-wó 2PL child-PLTP 2PL-set ear 2PL parent-PL 'You children, obey your parents.'

(28a) is a negative imperative which is discussed below. As noted above, the illocutionary force of the imperative constructions can be modified by several utterance final particles. Other speech formulae of the please type such as mede kúkú 'I remove my hat', taflatsé 'please' and káfra 'please' can be used to attenuate the force of imperative utterances (Ameka 1991, 1994 and see also Keleve 2002). Typically such forms occur preposed to the imperative construction.

\subsection{First person imperative (Hortative)}

Like the second person imperatives, the first person plural imperative has a 1PL pronominal subject followed by the verb phrase. Like the second person plural, the minimal imperative structure involving the 1PL pronoun mi can be interpreted either as an imperative or a non-imperative. Structures of the kind with a non-imperative can be paraphrased using the extended forms of the pronoun. Compare the following utterances which differ in their illocutionary point, due in part to the form of the subject pronoun, but which take the same illocutionary force modifiers:

(29) a. [An invitation to join in a meal]

me-de kúkú mí-du nú sea

1SG-remove hat 1PL-eat thing UFP

'Please let's eat, y'hear' / 'please we have eaten, y'hear'

b. [A response to a question about whether they have eaten]

me-de kúkú mié-du nú sea

1SG-remove hat 1PL-eat thing UFP

'Please we have eaten, y'hear' 


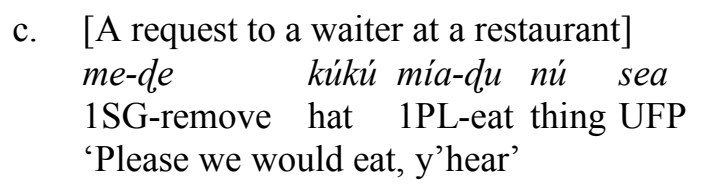

The utterance in (29a) is a commonly heard invitation that is extended to people around when one is about to have a meal. However, it can also be interpreted as a statement of something that has happened. The ambiguity is absent from the sentences in $(29 b, c)$ where they can only be interpreted as statements and not as a 'mand' to use Lyons' (1977: 745) term. Roughly speaking, the illocutionary point of the first person imperative or hortative is 'I want us (you and 1) to do something (together)'. Like the second person imperatives, the first person plural imperative can co-occur with topic and/or vocative phrases.

\subsection{Third person imperative: the jussive}

Third person imperatives are marked by a form né 'let, JUSSIVE' that occurs between the Subject and the verb complex. This marker occurs in many routine expressions such as the response to the introductory phrases for the performance of different genres of verbal arts. Consider the following adjacency pair:

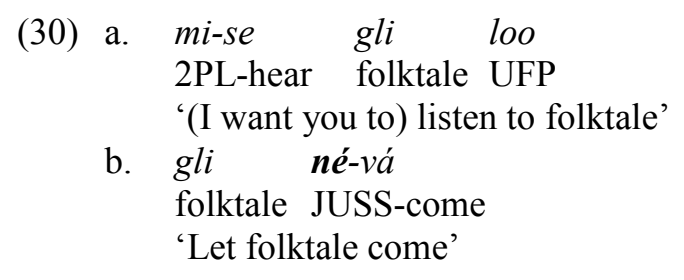

Similarly, an elaborate response to agoo, the expression used to request access or entry to a place, makes use of the third person imperative as illustrated in (31).

$$
\begin{aligned}
& \text { agoo né-no } \quad \text { kpó gódo ame } \\
& \text { 'agoo' JUSS-be.at:NPRES fence outside person } \\
& \text { né-gé dé me } \\
& \text { JUSS-fall ALL inside } \\
& \text { 'Let agoo stay outside (the fence/wall) and let a human being en- } \\
& \text { ter.' }
\end{aligned}
$$

The subject NP can be marked for plural as in the phrase in (32) used during a cleansing ritual.

$$
\begin{aligned}
& \text { gbogbo vर̃́-wó né-do } \\
& \text { spirit bad-PL JUSS-exit } \\
& \text { 'Let evil spirits come out.' }
\end{aligned}
$$


If the subject is a third person plural pronoun, it is overtly realised. However when it is the third singular pronoun, it is not expressed. For example
a. wó-né-blá wò
3PL-JUSS-tie 2SG
'They should tie you.' (Bidi Setsoafia 1989: 16)
$\begin{array}{lll}\text { b. } & \text { né-ga-tu } & m i \\ & \text { JUSS-REP-meet } & 1 \mathrm{PL}\end{array}$
'Let it come to meet us again.' (response to New Year wish) ${ }^{3}$

Two features of the jussive are its irrealis nature and the desire (want or wish) of the speaker for a state of affairs to occur. As such the jussive is closely related to the subjunctive and, in some contexts, the two forms are interchangeable as shown in the example below.

$$
\begin{aligned}
& \text { Máwú ná- / né-yrá wò dáá } \\
& \text { God SUBJV-/ JUSS-bless 2SG always } \\
& \text { 'May God bless you forever.' }
\end{aligned}
$$

(This intersubstitutability has lead to the situation in some dialects such as Kpele where the distinction between the subjunctive $n a ́$ and the jussive né is lost, Chris Collins p.c. See also Westermann 1930:76-7 who suggests that né and $n a ́$ are alternates for the third person imperative.) The jussive form né plays a crucial role in multiclausal imperative constructions. These structures are discussed after a description of the prohibitive.

\subsection{The prohibitive}

The negative imperative or the prohibitive is formed by the negative marker plus the verb marked by the repetitive preverb marker $g a$ 'REP'. It is as if to say 'I want you not to do something again'. For example:

$$
\begin{aligned}
& \text { a. me-ga-fa avi o } \\
& \text { 2SG:NEG-REP-emit cry NEG } \\
& \text { 'Don't cry.' } \\
& \text { b. mi-(mé)-ga-fa aví o } \\
& \text { 2PL-NEG-REP-emit cry NEG } \\
& \text { 'Don't cry (you plural).' } \\
& \text { c. né mé-ga-du dze o } \\
& \text { JUSS 3SG:NEG-REP-eat salt NEG } \\
& \text { 'Let him/her not eat salt.' }
\end{aligned}
$$

The low tone of the subject in (35a) has been absorbed by the inherent tone of the negation marker mé which shows that the subject is indicated just as in the positive imperative. In $2 \mathrm{PL}$, the negation marker is enclosed in optional 
brackets because in some dialects it is elided. The interaction between the second person pronouns and the negative in this context is not unique. It applies across the board and is not restricted to the imperative context (see e.g. Duthie 1996).

\subsection{Embedded imperatives}

When a $2 \mathrm{SG}$ imperative is quoted there is no difference in form. The $2 \mathrm{SG}$ imperative structure is merely embedded in the quotative phrase, as in (36a). However, when such an imperative is reported, it is optionally introduced by né 'JUSS' after the quotative complementiser be' 'QT' and the verb is marked for the subjunctive or more generally, the irrealis (see e.g 36b). Similarly, for embedded 2PL and 1PL imperatives, the jussive né form is optional and the 'mand' may be in the imperative form or it may be expressed using the subjunctive, see the examples in (37).
a. É-bé vă
3SG-QT 2SG:come
'S/he said: come.'
b. É-bé (né) na-vá
3SG-QT JUSS 2SG:SUBJV-come
'S/he said you should come.'

(37)
a. É-bé (né) mi-vá/ mia-vá
3SG-QT JUSS 2PL-come 2PL:SUBJV-come
'S/he said come, (you plural) / you (plural) should come.'
3SG-QT JUSS 1PL-come 1PL:SUBJV-come
'S/he said come (to us) / we should come.'
b. É-bé (né) mí-vál mía-vá

In the sentences above, where the jussive is absent and the verb form is not marked for the subjunctive, the form could be interpreted as a quotative as I tried to capture in the free translations.

A third person imperative can also be embedded either without modification or it may be expressed using the subjunctive. Consider the following text example in (38) and its subjunctive counterpart in (39):

$$
\begin{array}{llllll}
\text { é-gbls ne } \quad b e ́ & n e ́-g e ́ & d e ́ & k a ́ a & l a ́ & m e . . . \\
\text { 3SG-say DAT:3SG QT JUSS-fall ALL car DEF inside } \\
\text { 'He said to him get into the car...' (Hlomatsi } 1994 \text { [1291]) }
\end{array}
$$




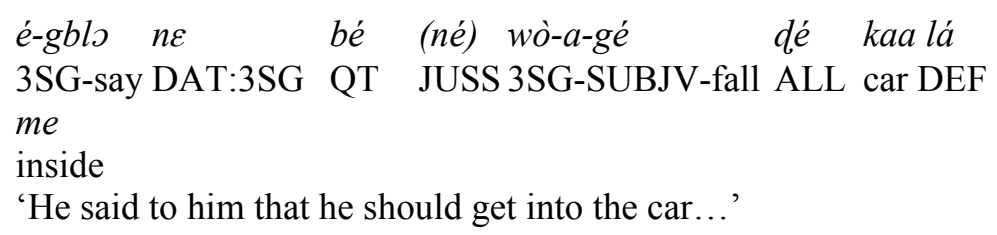

The example in (38) is a quoted 3SG imperative and the jussive marker cannot be left out. If the 'mand' was expressed using the subjunctive it would be optional and if the jussive né form is present, it would occur just after the quotative bé and before the subject pronoun. The sentence in (39) is a reported paraphrase of the embedded imperative in (38).

We note, firstly, that the form né 'JUSS' is optionally used to introduce embedded imperatives. Secondly, the use of the né form is not restricted to third person environments. Thirdly, in these embedded imperative contexts where né can be used, the clauses that can be introduced by it are either imperative or subjunctive clauses, both of which grosso modo can be understood as irrealis. It is shown in the next section that né is used as a connector in multiclausal imperatives. Like the embedded contexts, the structures involved are irrealis clauses.

\subsection{Multiclausal imperatives}

The most common imperative structures that are combined into multi clausal structures involve different persons. Typically a second person imperative is combined with a first person plural imperative, or a third person imperative with that of a first or second person plural. In all these cases, the constructions are either just juxtaposed or they are linked by the form né, which, I would argue, is related to the jussive marker. In what follows, I illustrate the various kinds of multiclausal imperatives and develop the claim that the jussive marker has evolved into a consecutive connector.

A common multiclausal imperative that is often heard is the invitation to join a meal where the first part is a second person imperative and the second part is a first person imperative. The connection between the two can be overtly marked by né 'LINK'.

$$
\begin{aligned}
& \text { vă / mi-vá (né) mí-qu nú } \\
& \text { 2SG:come 2PL-come LINK 1PL-eat thing } \\
& \text { 'Come (sg/pl) let's eat.' }
\end{aligned}
$$

In (40) the subsequent clause is in the imperative. The 'mand' in the second clause can, however, also be expressed as a subjunctive, as illustrated in (41). Note that the overt connector $n e ́$ is optional. 


$$
\begin{array}{lll}
m i-v a ́ & \text { (né) } & m i ́-a-q u-i \\
\text { 2PL-come } & \text { LINK } & 1 \mathrm{PL}-\mathrm{SUBJV}-\mathrm{eat}-3 \mathrm{SG} \\
\text { 'Come let's eat.' (a line from a children's play song) }
\end{array}
$$

There is a restriction on second person imperatives in these multiclausal structures, namely that a second person imperative cannot occur as the subsequent clause to another imperative or even subjunctive clause. In other words, second person 'mands' in non-initial position in complex structures have to be marked for the subjunctive. The use of né 'LINK' although not obligatory is highly preferred in such structures.

$$
\begin{array}{llll}
\text { wo kábá né } & m i-*(a)-y i & \text { agble } \\
\text { 2SG:do quickly } & \text { LINK } & \text { 2PL-SUBJV-go } & \text { farm } \\
\text { 'Hurry up (sg) and you (pl) go to the farm.' (A mother to a child) }
\end{array}
$$

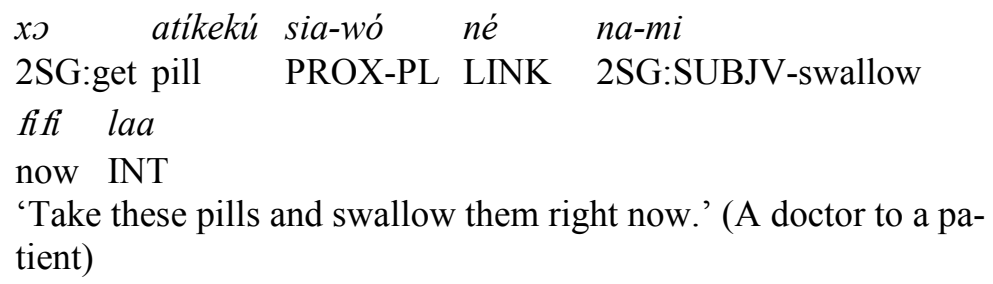

In (43) the two commands are addressed to the same person, nevertheless the second is expressed as a subjunctive clause. The first is in the imperative form and both are linked by the connector né. Recall however that an SVC can be used to package two or more second person imperatives that are construed as belonging together more tightly. Thus the same scenario represented in (43) could be packaged in an SVC as in (44).

$$
\begin{array}{llll}
x \supset \quad \text { atikekú } & \text { sia-wó } m i \quad \text { fifi laa } \\
\text { 2SG:get pill } & \text { PROX-PL swallow now } & \text { INT } \\
\text { 'Get these pills and swallow them right now.' }
\end{array}
$$

It is evident from the examples discussed so far that the form né is used as a linker of clauses expressing 'mands' which are coded either as imperatives or as subjunctives. In the case of embedded imperatives, the né form is followed by a clause that is either an imperative or a subjunctive. This restriction does not apply to the matrix clause. The né form is optional in such a context except when the 3SG imperative is being quoted. In the case of the multiclausal structures, the clauses being connected have to agree in irrealis, that is, either, all imperative, all subjunctive or the first one an imperative and the subsequent one a subjunctive. Furthermore, the presence of né as a linker is preferred in second person structures. This is coupled with the restriction that a second person imperative cannot occur in non-initial position in these multiclausal struc- 
tures. I suggest that these structures provide the bridging context for the grammaticalization of the jussive marker as a consecutive linker. In the next section, I show that the clauses that are linked by the form né outside the imperative domain are irrealis clauses-a feature that is common to the clauses in the multiclausal imperatives.

Before turning to that, the question may be asked what kind of nexus is between the clauses linked by né. These clauses are non-embedded but they seem to be dependent on each other in terms of a mood operator. That is, the clauses have to agree in the feature irrealis-broadly defined. This kind of nonembedded operator dependent relationship has been called co-subordination in Role and Reference Grammar (RRG) (Van Valin and LaPolla 1997).

\subsection{Connective function of né in non-imperative contexts}

The contexts in which né is used that have been considered so far all involve a 'mand'. The combined clauses discussed in the immediately preceding section have in addition to this, two other features. They are all irrealis as mentioned above. However, they also all involve an iconic ordering of the sequence in which the states of affairs are to be manifested. That is to say, apart from the irrealis operator dependence between the clauses they also have an 'after' relation. A rough paraphrase of the relation between two clauses of the kind described above could be something like this:

I want you to do something (e.g. come here in example 40 above)

After you have done this (after you come here)

I want you to do something else (I want you to eat with me)

The two features of irrealis and 'after' underlie the use of the né connector in non-imperative contexts. In these contexts, né can occur as the sole connector of two or more irrealis clauses. The clauses are interpreted as having a sequential relation and can be paraphrased as having an 'and then' (45a) or a purposive 'so that' relation $(45 b)$.

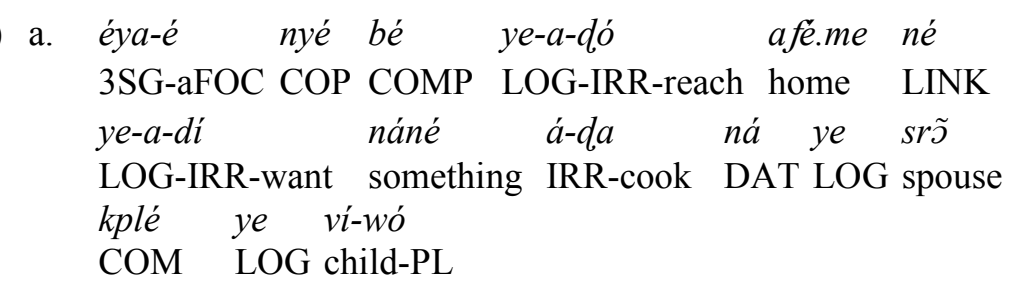

'That is that she should get home and find something to cook for her husband and children.' (VLB no date: 1) 
b. mía-nyro-e dé to-a me 1PL:IRR-immerse-3SG ALL river-DEF containing.region né wò-a-no tsi kú

LINK 3SG-IRR-drink water die

'We should immerse him in the river so that he would drown.'

The common denominator of the linked né clauses is that there is a relation of consecutiveness or sequence between them: one follows the other and the purpose reading is an implication derived from this iconic ordering. It seems as if the first state of affairs occurs to enable the other state of affairs to take place.

In the examples discussed here, the né form occurs as a connector between two or more clauses and each of them is a kind of irrealis. In other contexts the linker $n e$ functions to introduce other clauses. It seems as if this is another stage in the grammaticalization which is linked both to the embedded imperative uses and to the consecutive connector functions in the following sense. The clauses that are introduced by the linker are irrealis clauses or the contexts are unreal situations. This is consistent with the uses that have already been outlined.

The apodosis clause of a counterfactual conditional is introduced by the né linker. Even though the clause it introduces need not be marked for the irrealis the context of the state of affairs being characterised in the sentence cannot occur. The protasis clause of a counterfactual conditional in Ewe is introduced by dě 'COND'. ${ }^{4}$ It is sometimes left out in more routinized expressions such as proverbs, as shown in (46b).

$$
\begin{aligned}
& \text { a. dě me-nye bé á-no áléá } \\
& \text { COND 1SG-know:3SG QT 3SG:IRR-be.at:NPRES thus } \\
& \text { né me-gbugbo dé megbé } \\
& \text { LINK 1SG-return ALL back }
\end{aligned}
$$

'Had I known that it would be like this, I would have withdrawn.'
b. te-tí-tu-gbe-é wó-du-a te lá,
yam-stick-fix-day-aFOC 3PL-eat-HAB yam TP

né gbo má-kpó tsyró-á á-du o

LINK goat NEG:IRR-see skin-DEF IRR-eat NEG

'Were yams eaten on the same day as the day for fixing poles for the yam plant, the goat would not even get the skin to eat.' (a proverb)

It is plausible that from its use as introducer of counterfactual apodosis, the $n e ́$ linker came to be used as the introducer of the protasis of simple conditional clauses. I suggest that the bridging context of this could have been the prepos- 
ing of the né introduced clause as a scene-setting clause and marked by lá 'terminal topic particle'.

Adverbial or dependent clauses expressing condition, time, reason, purpose etc. can either be preposed or postposed to the matrix clause. When they are preposed to the main clause they have a scene-setting or framing function and they are marked by the terminal backgrounding particles lá or dé (see e.g. Ameka 1990b). The suggestion here is that when the counterfactual apodosis occurs initially, followed by another clause introduced by né, this gave rise to a hypothetical conditional reading. It is such a clause with a hypothetical reading that provided the context for the specialisation of né as a conditional marker.

Another context in which the connective marker occurs is as the introducer of complement clauses of the verb suss 'remain' and its synonym kpots 'remain' when they occur with an expletive or cataphoric pronoun as in expressions used in telling the time.

$$
\begin{aligned}
& \text { é-suso míniti ewó né } \\
& \text { 3SG-remain minute ten LINK metal eight SUBJV-hit } \\
& \text { 'Its ten minutes to eight' }
\end{aligned}
$$

In such structures, the complement is always marked for the subjunctive and the linker can be elided. These features are consistent with the features we have seen so far for the connective function of the linker.

Similarly, né 'LINK' can optionally double with other connectives when they introduce irrealis complements. Thus it co-occurs with be 'QT/COMP' when it introduces purpose clauses as in (48a) and with temporal connectives such as háfi 'before', káká 'by the time' or kásiá 'just then' when they introduce irrealis clauses as in (48b). Consider these examples:

$$
\begin{aligned}
& \text { a. é-tsó atí bé (né) ye-a-fo-e } \\
& \text { 3SG-take stick COMP LINK LOG-SUBJV-strike-3SG } \\
& \text { 'S/he took a stick in order to hit him/her' } \\
& \text { b. háfi (né) yu ná-ke lá, wó-dzó xóxó } \\
& \text { before LINK eye SUBJV-open TP 3PL-leave already } \\
& \text { 'Before it was dawn, they left already' }
\end{aligned}
$$

It is probably the irrealis feature that is drawing the né connective into these connective doubling environments. The reason for saying so is that when the connectives that né 'LINK' doubles are not introducing irrealis complements, $n e ́$ cannot optionally occur with them. A sentence initial há $f i$ 'before' clause of the kind in (48b) will always be an irrealis clause hence né can also occur in such clauses. When the háfi clause is postposed however, it need not be an irrealis clause and hence né is ruled out if the clause is not explicitly marked for the irrealis (see Clements 1972). Sentence (48b) can be re-expressed as (49) 
where the háfi clause is postposed. Notice that the linker né is unacceptable since the clause is not irrealis.

$$
\begin{array}{llll}
\text { wó-dzó xóxó háfi } & \left({ }^{*} n e ́\right) & \eta u & k e \\
\text { 3PL-leave already before } & \text { LINK } & \text { eye } & \text { open } \\
\text { 'They left long before day break' } & &
\end{array}
$$

To sum up, I have tried to argue that the varied uses of the form né in Ewe grammar are all linked heterosemically. I have in the course of the discussion suggested a grammaticalization chain with different stages from a jussive-a third person imperative-to a consecutive connector. This scenario for the relations is displayed in Fig 2.

Figure 2: relations between the various functions of né

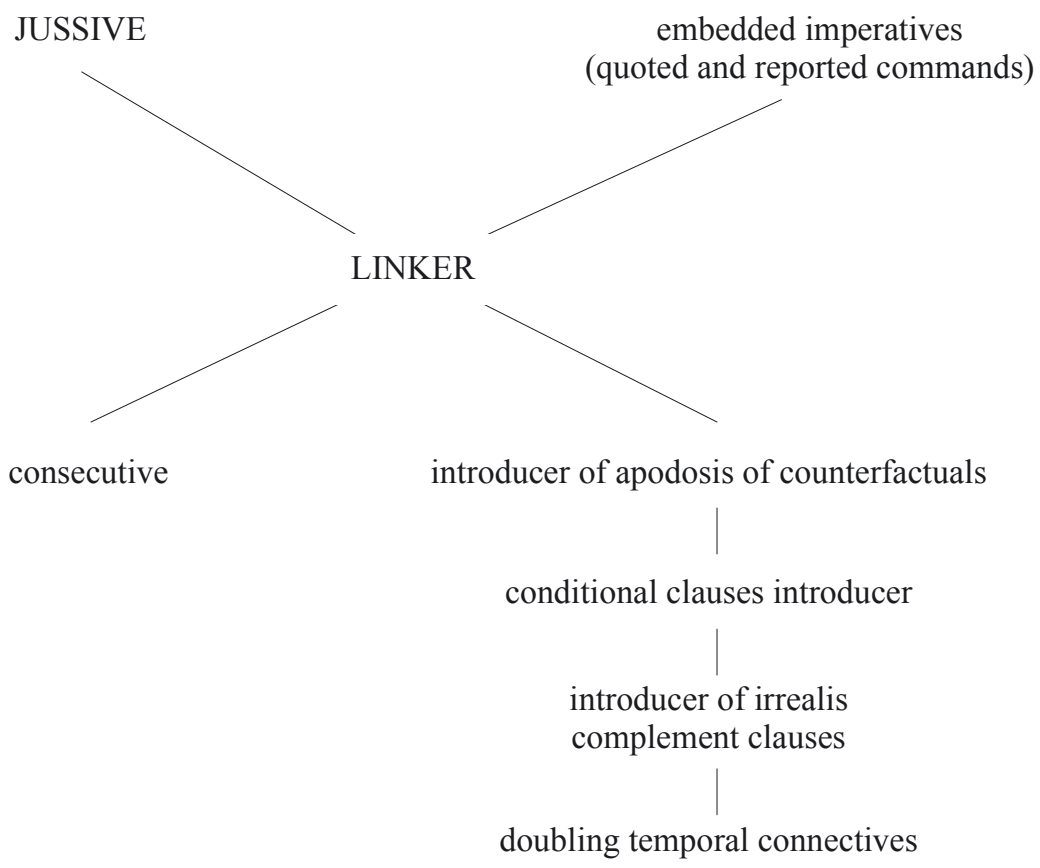

This development is of theoretical interest both for the study of clause combining and for grammaticalization. Verstraete (2002) hypothesises that interactional meaning is the most crucial functional principle for understanding clause combining. The development of a jussive-a clause type or mood indicator to a clause connector, in a way, would appear to give prima facie support to 
such a hypothesis since the jussive involves a speaker-locutor interaction. From the point of view of grammaticalization, I am not aware of instances of such a development being noted in the literature. Of course, the development type itself is not unexpected: from a more interpersonal marker to a textual meaning indicator (cf. e.g. Traugott 1988).

\section{$6 \quad$ Adverbial aspectual constructions}

After surveying various aspect, mood and modality markers inside the verb complex, we now turn to the markers and constructions that encode aspectual meanings largely outside the verbal complex. These include adverbial aspectual markers, discussed in the present section, periphrastic phasal aspect constructions, described in section 7, and the proximative construction presented in section 8 .

There are three adverbials that pertain to the terminal viewpoint of situations or the coda. These are vo 'COMPL', sé 'CESS' and kpó 'PFV'. The completive vo signifies that something has happened or has been done completely. When it is used with instantaneous actions and developments or with triplication, it indicates that a situation is about to be completed. By contrast, cessative $s e ́$ indicates that a situation has been terminated and it is incomplete, while the perfective kpó symbolises the existential and experiential status of situations. To emphasise the non-manifest status of situations kp' may be triplicated in a negative clause (see section 6.3). The difference between the completive $v o$ the cessative sé and the existential perfective kpó in terms of the coding of the terminal viewpoint of situations can be seen in the different contexts in which the utterances in (50) can be used.

$\begin{array}{llll}\text { nyónu má } \quad \text { dzi ví / vo / kpó } \\ \text { woman } & \text { DIST bear child CESS COMPLPFV } \\ \text { CESS: } & \text { 'That woman has stopped having children.' } \\ \text { COMPL: 'That woman has finished having children.' } \\ \text { PFV: }\end{array}$

The cessative version is used in a context where there is nothing biologically to prevent the woman from having children, but she has decided not to have any more children. The completive version, however, is used to indicate that the woman has exhausted her capacity for having children and therefore cannot have any more children. She is probably past her menopause. The existential perfective version indicates that the woman has had the experience of bearing a child before; she is not barren.

Each of these adverbials has a verbal counterpart from which it has grammaticalized in the context of multiverb constructions (cf. Lord 1993, Heine and 
Reh 1984 and Ameka 2006). The form vo 'COMPL' has developed from an overlapping biclausal construction of the kind illustrated in (51b) where it functions as the main verb in the second clause (Ameka 2003). In such an overlapping clause the subject of the subsequent clause is coreferential with a nonsubject argument in the first clause. The other forms sé 'CESS' and $k p$ ' 'PFV' seem to have grammaticalized in final position in serial verb constructions (Ameka 2006). The instances of the forms vo, sé and kpś which function as aspectual adverbials are those where they i) occur after another verb, i.e. as post-verbal modifiers, and ii) do not occur with preverbs or the habitual suffix $n a$. Thus $v o$ 'COMPL' occurs in a monoverbal clause in (51a) and functions as an adverbial that marks completive aspect and it cannot be marked for any verbal categories, but the same surface form occurs in the second clause in the overlapping clause structure in (51b) and is a full verb. It is marked here for the potential by a preverb. Consequently, the two sentences have slightly different meanings, as the English equivalents suggest:

$$
\begin{array}{llll}
\text { a. } & \text { deví-á-wó } & \hat{a}-q u \quad \text { nú-á } & \text { vo háfí } \\
\text { Child-DEF-PL } & \text { POT-eat thing-DEF COMPL before } \\
\text { á-yi suku } & & \\
\text { POT-go school } &
\end{array}
$$

'The children will eat the food (completed) before they go to school.'

b. devî-á-wó $\hat{a}-d u \quad n u ́-a ́ \quad$ wò-a-vo háfí

Child-DEF-PL POT-eat thing-DEF 3SG-POT-finish before á-yi suku

POT-go school

'The children will eat the food and it will be finished before they go to school.'

Similarly, the occurrences of sé 'CESS' and $k p s$ 'PFV' in (52b) and (53b) respectively are the exponents of the perfective category, and are the instances of concern to us:
a. $m-a-x l \tilde{e}$
agbale
sésế má á-sé
dé afiì
1SG-POT-read
book
hard DIST POT-stop
ALL here
'I will read that difficult book and I will stop here.'
b. $m-a-x l \tilde{e}$ agbalẽ sésế má sé dé afii 1SG-POT-read book hard DISTCESS ALL here 'I will read that difficult book and stop here.'


(53)
a. kofí â-liá gemí-tó á-kpó tógó dá
NAME POT-climb NAME -mountain POT-see NAME in.the.distance
'Kofi will climb Mt.Gemi and will look at Togo (from there).'
b kofí â-liá gemító kpó
NAME POT-climb NAME -mountain PFV
'Kofi will climb (try to climb) Mt Gemi (and see).'

The forms are considered to be adverbials for two reasons: firstly, these items can occur after other adverbials. In (54) $v o$ 'COMPL' occurs after an adverbial phrase of comparison.

$$
\begin{aligned}
& \text { áma kó abé fofó-á ené vo } \\
& \text { NAME become.tall as father-DEF as COMPL } \\
& \text { 'Ama is almost as tall as the (=her) father.' }
\end{aligned}
$$

Secondly, the forms $k p$ ' 'PFV' and $v o$ 'COMPL' can be triplicated as discussed in sections 6.1 and 6.3. Triplication is a feature of adverbials (and nominal intensifiers, see (55)), but not of verbs and preverbs. Hence these forms are adverbials.

$$
\begin{array}{ll}
\text { deví má ko-koo-ko-é } & \text { tsó-e } \\
\text { child DIST TRIP-TRIP-only-aFOC } & \text { take-3SG } \\
\text { 'ONLY THAT CHILD took it.' } &
\end{array}
$$

Moreover, vo 'COMPL' and kps 'PFV' can co-occur with their verbal counterparts as illustrated in (56 a, b).

$$
\begin{aligned}
& \text { a. atíke-a vo vo } \\
& \text { medicine-DEF finish COMPL } \\
& \text { 'The medicine is almost finished.' } \\
& \text { b me-do domedzui nenémá me-kpś kpś o } \\
& \text { 2SG:NEG-put anger such 1SG-see PFV NEG } \\
& \text { 'I have never seen you that angry.' } \\
& \text { Lit: 'You have not been that angry I have seen before' }
\end{aligned}
$$

Such sequences are indicative of the 'deverbal' status of the dependent instances of forms (see discussion of nyá modals in section 2.2.3).

\subsection{The completive marker vo}

The situations that $v o$ 'COMPL' co-occurs with must be segmentable into temporal phases. Consequently, it does not occur with states or with 'sharp' achievements (Dillon 1977: 36), as the ungrammaticality of (57a) and (58a) 
show respectively. By contrast, it occurs with change of state situations (57b) as well as gradual achievements (58b) which can be temporally segmented. In these contexts, as the translations indicate, the marker has two possible interpretations: total completion and imminent completion.
a. *ga le así-nye vo
money be.at:PRES hand-1SG COMPL
$\neq$ 'I have money.'

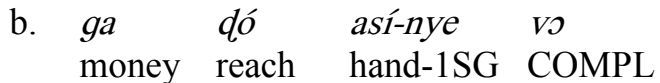
'I have got (acquired) money' / 'I am about to have money.'
(lit. Money has/ is about to reach my hands.)

(58) a. *nya lá lílí mí vo

word DEF surprise 1PL COMPL

'We were taken by surprise' / 'The case happened unexpectedly.'

b. nya lá dzo vo

word DEF happen COMPL

'The case happened/ is about to happen'.

As just indicated, the completive marker $v o$ has two readings. One factor that determines the interpretation in a particular usage is the type of situation characterised by the verb phrase or clause it modifies. When vo 'COMPL' modifies homogeneous activities, i.e. processes, it has a total completion or accomplishment reading, namely, all of the process occurred by the reference time, see (59a). When it occurs with bounded events, i.e., instantaneous actions, as in (59b), and developments, it has an imminent completion reading, namely, the last part or moment of the situation is about to happen.

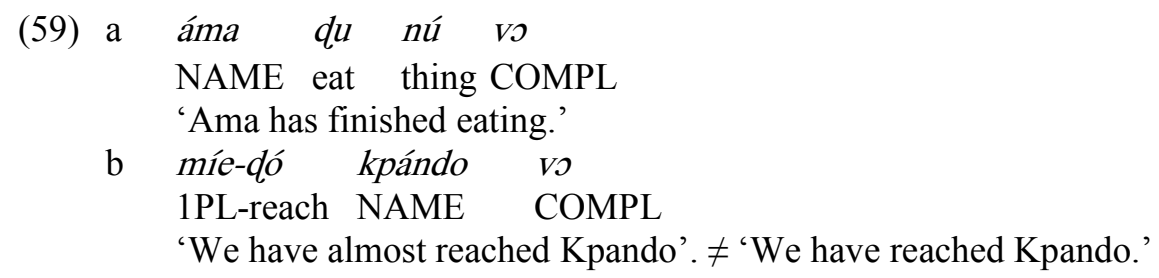

For both interpretations, the situations are perceived in their entirety as a whole. This is the feature that distinguishes the completive $v o$ from the cessative sé marker. The latter does not co-occur with totality expressions such as kátã 'all', kéy 'completely' and blîbo 'whole' while the former does, as illustrated in $(60)$. 


wó-no lá kátã vo / *sé
3PL-drink oil.palm-alcohol DEF all COMPL CESS
'They drank up all the wine' / ? 'They stopped drinking all the
wine'

Strictly speaking, the description of $v o$ 'COMPL' as a marker of an 'accomplished action' as reflected in statements such as Pazzi's (1970:117) "action achevée" and Westermann's (1930) glosses of 'finished up, that's all' are only appropriate for characterising the form when it occurs with processes.

The two interpretations of $v o$ 'COMPL' described so far can be related to the temporal phases of situations. With processes, for instance (59a), vo 'COMPL' codifies the attainment of the last moment of a situation. With punctual occurrences, as in (59b), $v o$ 'COMPL' indicates that the preparatory stage is taking place, while with developments, it shows that the last moment leading up to the total accomplishment of the situation is in progress. The reality of these readings is evidenced by the fact that when vo 'COMPL' occurs with some events which could be thought of as having relative terminal points, the two interpretations are possible. With events involving predicates such as tsi 'grow up', $d i$ 'ripe', vó 'rot', the judgement of individuals with respect to the point at which they have become accomplished could vary. This leads to ambiguous utterances such as those in (61).

$$
\begin{aligned}
& \text { a. akodú lá di vo } \\
& \text { banana DEF become.ripe COMPL } \\
& \text { 'The banana is completely ripe.'/'The banana is almost ripe.' } \\
& \text { b. deví sia tsi vo } \\
& \text { Child PROX grow.up COMPL } \\
& \text { 'This child is quite grown.' } \\
& \text { 'This child is perfectly mature.'/ 'This child is almost of age.' }
\end{aligned}
$$

One of the uses of the completive $v o$ form in connected discourse is the sequencing of events or propositions: that is, to mark situations that are prior in time to the other situations to which they are linked. In (62) the abusive behaviour towards the speaker happened prior to the request for marriage.

$$
\begin{aligned}
& \check{a}-d z u-m \text { le ame dome vo, } \\
& \text { 2SG:POT-insult-1SG LOC people among COMPL } \\
& \text { háfi á-vá de-m=a } \\
& \text { before 2SG:POT-VENT marry-1SG=Q } \\
& \text { 'Would you have finished swearing at me in public before coming } \\
& \text { to marry me?' }
\end{aligned}
$$


In sum, the completive marker $v$ occurs with non-static situations and has two senses: one of total completion and the other of imminent completion. In context, the interpretation depends on the semantic and aspectual properties of the situation involved. The first interpretation, which I assume to be the primary one, applies to homogeneous activities, i.e. processes, whether they are bounded or not. The second one applies to bounded events i.e. instantaneous actions and developments.

A further means of indicating that a non-static situation is about to be completed is by the triplication of the completive marker vo (see Ameka 1999 on the mechanisms of reduplication and triplication in Ewe). ${ }^{6}$ Thus for either processes or events one can triplicate $v o$ to express the idea that a situation is very close to completion. In one sense, the triplication of $v$ with events emphasises the very imminent nature of the achievement of the terminal point of such situations (see 64). With processes, the triplication of $v$ indicates that a situation is going through the last part of its evolution (see 63):

$$
\begin{aligned}
& \text { áma no de.tsi-a vo-vos-vo } \\
& \text { NAME drink soup-DEF TRIP-TRIP-COMPL } \\
& \text { 'Ama has almost finished/is on the point of finishing eating the } \\
& \text { soup.' }
\end{aligned}
$$

\begin{tabular}{|c|c|}
\hline$a w u-a-w o ́$ & ขว-ขวว-ขว \\
\hline $\begin{array}{l}\text { garment-DEF-PL become.dry } \\
\text { 'The garments are almost dry.' }\end{array}$ & TRIP-TRIP-COMPL \\
\hline
\end{tabular}

$\begin{array}{lll}\text { mamá-nye } & \text { háyá } & \text { və-vวग-və } \\ \text { grandmother-1SG } & \text { recover } & \text { TRIP-TRIP-COMPL }\end{array}$
'My grandmother has nearly recovered from her sickness.'

The imminent completion reading of the completive marker when it occurs with developments and punctual situations as well as when it is triplicated suggests that linguistic indicators of perfectivity may also encode the meaning of imminent completion in a language. Cross-linguistic surveys of the perfective category have noted ingressive or inceptive meaning as one of the senses of perfective forms (see Comrie 1976, Bybee 1985, Chung and Timberlake 1985, Dahl 1985). Imminent completion as an aspectual meaning does not seem to have been recognised for perfective categories in the literature. However, this is clearly the case in Ewe, as we have shown, and in some other languages such as Turkana, a Nilotic language of N.W. Kenya, and Kinyarwanda, a Bantu language of Rwanda (Botne 1983). According to Dimmendaal (1983:150ff) Turkana has a morphological aspect marker $-I t^{`}$ which indicates perfectivity and has the meaning of totality of completion with its focus of attention on completion. This sense is exemplified in (66) taken from (Dimmendaal 1983:150): 
(66)

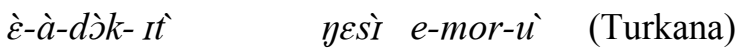

$$
\begin{aligned}
& \text { 3-PAST-climb-PFV he mountain } \\
& \text { 'He climbed the mountain (and came down again).' }
\end{aligned}
$$

However, with "ingressive" verbs, "[T]he semantics of these completive constructions is not always present" (Dimmendaal 1983:151). Notice that in (67) the event has not been accomplished. I suggest that in this case the perfective marker indicates imminent completion.

$$
\begin{aligned}
& \grave{\varepsilon}-\grave{a}-t w \grave{a}-n-I t \quad \eta \grave{S_{S}} \quad \text { (Turkana) } \\
& \text { 3-PAST-dead-SG-PFV he } \\
& \text { 'He almost died.' (Dimmendaal 1983:151 ex 8) }
\end{aligned}
$$

Thus perfective aspectuals, not only in Ewe, but also in Turkana (and Kinyarwanda and perhaps many more languages) are used to express imminent completion, especially of events - developments and punctual occurrences.

\subsection{The cessative marker sé}

The main difference between the completive marker $v o$ and the cessative marker sé lies in completeness: the former presents a situation as complete, while the latter presents a situation as incomplete. The cessative sé marks a situation as one which is not necessarily completed but is no longer happening and will no longer occur. Typically, it is used to describe habits or repeated actions or durative situations that have been stopped. Consider example (68):

$$
\begin{aligned}
& \text { kofi no sigaréti sé } \\
& \text { NAME drink cigarette CESS } \\
& \text { 'Kofi has stopped/quit smoking.' }
\end{aligned}
$$

The situation characterised by sé 'CESS' is perceived as having the potential to go on beyond the point at which it has been stopped. Thus it is not appropriate to describe punctual occurrences with sé 'CESS', as shown in (69):

$$
\begin{aligned}
& \text { *atî-á kú sé } \\
& \text { tree-DEF die CESS } \\
& \text { ?'The tree has stopped dying.' }
\end{aligned}
$$

However, the marker could occur with punctual occurrences if the subject is plural, indicating a kind of distributed cessation. Contrast (69) with (70a):

(70) a. atî-á-wó kú sé tree-DEF-PL die CESS

'The trees have stopped dying.' 


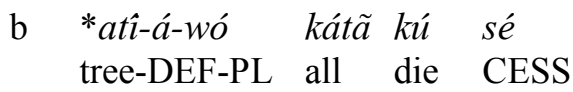

'The trees have stopped dying.'

The implication of (70a) is that some members of the group or class of trees have not yet died, but none of them will die any more. Compare this with (70b) which contains a totality expression implying that the whole situation of all the trees dying has been completed and since the cessative marker entails incompleteness, it is unacceptable in this context:

The abrupt ending of a situation due to natural causes can also be described with the cessative marker, but not with the completive as illustrated in (71).

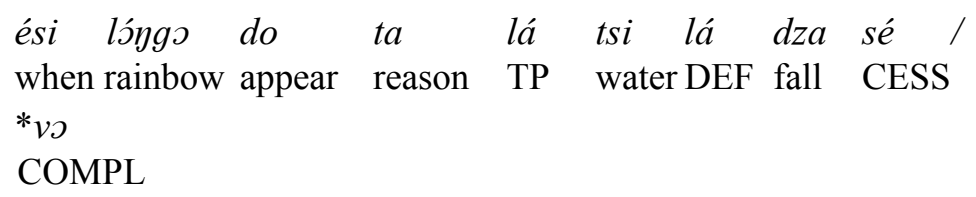

'Because a rainbow has appeared, the rain has stopped /

(*finished).'

To sum up, the cessative marker sé is used to mark situations that are terminated abruptly. It implies incompleteness. It is different from the other perfective markers - $v o$ 'COMPL' and $k p$ ' 'PFV' - in that it is not triplicated to express any nuance of meaning. This is probably due to its intrinsically abrupt nature. The abrupt cessation of a situation could not be construed as happening repeatedly or evolving to its terminal point.

\subsection{The existential/experiential perfective kps}

The marker $k p$ ' 'PFV' is very commonly used to describe situations that have existed before or will have existed after the moment of utterance. Thus in (72a) the situation has obtained before the speech time while in (72b) the situation will become manifest some time after the speech time:
a. fofó-nye gbls ná-m kpó bé
father-1SG say DAT-1SG PFV COMP
lã si nyá zo-zo lá fé dzo-é
animal REL know RED-walk TP POSS horn-aFOC
tró-ná
curl-HAB
'My father once told me that the animal which knows how to be- have itself is the one whose horns curl.' (Dogoe 1964:23) 
b. dzi.lá-wó $\hat{a}-g a-f o \quad n u \quad n a ́$ wó vî lá kpó parent-PL POT-REP-strike mouth DAT 3PL child DEF PFV 'The parents will (try to) speak again to their child.' (Dogoe 1964:13)

Previous descriptions of the form kps' 'PFV' have focused on its use with respect to past actions. Thus Pazzi (1970:117) observes that $k p \delta^{\prime}$ 'PFV' is used to characterise "action déjà accomplie autrefois" 'an action that has been completed once already'. English writers gloss the form as 'ever', 'once' and 'sometime' (in positive sentences), and as 'never', 'never as yet' (in negative sentences) (Warburton et al 1968:249, Westermann 1930:131). These glosses are not adequate for the use of kpś 'PFV' in contexts involving unrealised situations such as with the potential, as in (72b) or with imperatives, as in (73a) or progressive (73c) or prospective (73b) constructions.
a. no aha sia kpó
drink alcohol PROX PFV
'Have some of this wine (and see)'/'Try some of this wine.'
b. me-le é-du gé kpó
1SG-be.at:PRES 3SG-eat PROSP PFV
'I will eat it and see.'/'I will try it.'

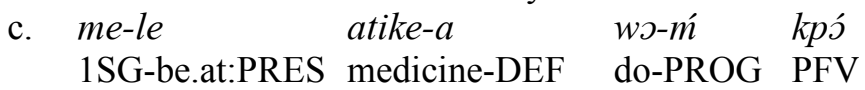
'I am taking the medication to see.'/'I am trying the medicine.'

With these not-yet-realised situations, as the glosses suggest, $k p s^{\prime}$ 'PFV' has an attemptive sense: 'try $\mathrm{X}$ and see'. The attemptive sense of $k p$ ' 'PFV' is not surprising from a cross-linguistic perspective. In many languages of the world, the verb 'see' or its grammaticalized form tends to be used for the expression of such a meaning. For instance, "conative modality (the actor tries to perform the action) is almost universally signalled in Papuan languages with a serial verb construction involving the verb stem see" (Foley 1986:152).

The use of kp' 'PFV' can be summarised as follows: it indicates a situation that has obtained prior to the moment of utterance. It can also have an attemptive sense with not-yet-realised situations, and indicate that some situation will have occurred after the moment of utterance. It seems that what is common to both readings is that at a certain time, specified by linguistic (temporal) markers, one can know something about the historical status of a situation. This is obvious for actions in the realis mode. For situations in the irrealis mode, in which the form has an attemptive sense, it can be argued that the main point about trying something is that at the end of it the one who performs the trial will have had the experience of the event. Furthermore, the expectation is that 
at the appropriate time the situation will have been accomplished and its existence established. $^{7}$

In negative utterances $k p \delta^{\prime}$ 'PFV' is used to indicate the non-existence of a situation, either before the speech time or after the speech time, as in $(74 a, b)$ respectively.
a. devî-á-wó mé-nyá kpó g̃̃ hã bé tó Child-DEF-PLNEG-know PFV even also COMP father le ye-wó sî o be.at:PRES LOG-PL hand NEG
'The children never knew that they even had a father.'
(lit.: The children did not even know for once that a father was in their hands.) (Motabiala Newspaper)
b. nye ma-wo-e kpó o
1SG NEG:POT-do-3SG PFV NEG
'I will never do it.'/'I will never try it.'

To emphasise that a situation has never obtained and will never obtain, one can triplicate the form kps ' $\mathrm{PFV}$ ' in a negative clause, as in (75). The strategy of kpś 'PFV' triplication, unlike that of $v o$ 'COMPL' triplication, is pandialectal; that is those dialects that do not triplicate $v o$ triplicate kpó in this context. However, unlike $v o$ triplication which can be either in positive or negative clauses, the triplication of kpó is restricted to negative sentences. Thus the triplicated form is unacceptable in (75b) which is the positive counterpart of (75a) where both the non-triplicated and the triplicated forms are acceptable.
a. nye-mé-se
nya má togbi kpó/kpó-kpóó-kpó o
1SG-NEG-hear word DIST such PFV TRIP-TRIP-PFV NEG
'I have never/ never, never heard such a thing before.'
b me-se nya má togbi kpó/*kpó-kpóś-kpó o
1SG-hear word DIST such PFV TRIP-TRIP-PFV NEG
'I have heard such a thing before.'

Many of the examples given so far involving the marker kpś 'PFV' have an animate entity filling the subject function in the clause. This could give the impression that the form is an experiential perfective marker. However, the subject argument in such clauses can be an inanimate entity as well, as in (76).

$$
\begin{aligned}
& \text { kú mé-di áléá kpś o } \\
& \text { drought NEG-shine such PFV NEG } \\
& \text { 'There has never been such a drought before.' }
\end{aligned}
$$

In such cases it is the existence or historical status of the situations which is being talked about, not the experience of some particular entity or sentient be- 
ing. It seems that a true experiential should go only with sentient beings. Hence it is more adequate to think of kpj 'PFV' as an existential perfective (cf. Johnson 1981 on existential status and Whorf 1956 on manifest/non-manifest status in Hopi).

\subsection{Summary of perfective markers}

The use and meaning of three Ewe adverbial forms that code perfectivity or the terminal viewpoint of situations have been explored in the preceding sections. It has been argued that $v o$ is a completive marker in the sense that it marks the total or imminent completion of a situation. By contrast, sé is a cessative marker that indicates the termination of a situation. The form kpó, on the other hand, is an existential perfective marker that signals the existence or historical status of situations. These three forms codify the semantic space of the end point of situations. Nevertheless each is a code for a specific part of that domain, as the labels and the analyses suggest.

The imminent completion reading of the completive marker $v$ s 'COMPL and of perfective markers in other languages like Turkana (Nilotic) and Kinyarwanda (Bantu) need to be integrated in cross-linguistic investigations of the meanings of perfective markers. In this connection it is worth noting that in English, imminent accomplishment of events is coded by the progressive (see Dillon 1977:126; Vlach 1981, and Bland 1988). Consider the examples in (77):

(77) a. Mary is dying.

b. John is winning.

c. The ship is arriving.

d. The plane is landing.

The progressive in these cases focuses on the onset or the moment that leads to the culmination of the events. It is significant that the verbs involved in the English progressive, are punctual verbs with onset just like those that trigger imminent completion when they combine with perfective markers in the African languages mentioned above. Further research might lead to the understanding of how the meaning of imminent completion of a situation is encoded in many more languages by aspectual markers, especially of progressive and perfective markers.

Furthermore, the semantics of the Ewe forms gives support to the claim that grammaticalization has a semantic basis-the sorts of meanings the Ewe aspectualisers have are deducible from the meanings of the lexical verbs from which they evolved. Indeed, it does not seem to be an accident that a verb meaning 'finish' should develop into a marker of the completion of situations. Nor is it strange, semantically, that a verb meaning 'stop/end' should become a marker of the termination of situations. Similarly the development of an existential 
perfective marker from a verb meaning 'see/experience' would appear to be fully motivated semantically.

\section{$7 \quad$ Phasal aspect constructions}

This section is concerned with linguistic expressions in Ewe used for characterising distinct intervals in the temporal development of situations. Following Freed (1979:30ff) it is assumed that situations (i.e. events, processes, actions and states, cf. Comrie (1976) and Mourelatos (1981)) are temporally segmentable into an onset - a first moment, which is a necessary and an obligatory preparatory stage in the ontogeny of every situation, a nucleus - a main part, and a $\operatorname{cod} a-\mathrm{a}$ final temporal phase. The nucleus can be further decomposed into an initial period, a middle, and a final part. Whilst it may be hard, in reality, (and perhaps impossible) to draw a line between the successive temporal phases of a situation, languages tend to provide linguistic forms for the description of such stages in the evolution of a situation. Thus English, for instance, has the aspectual verbs start and begin which are used to refer to the onset and the initial period of the nucleus of situations respectively (Freed 1979, Wierzbicka 1988). Similarly the verbs finish and end are used to code the final part of the nucleus and the coda respectively (Wierzbicka 1988:77-78, Dixon 2005). The markers of the onset, nucleus, and coda phases of a situation may be described as ingressive/inceptive, progressive/continuative, and egressive respectively.

The Ewe phasal aspect constructions all involve an operator verb (in one case an operator verb and a nominal obligatory complement) and a postpositional phrase complement. The dependent NP in the postpositional phrase is typically a referential event expression which is realised as a noun or a gerundive nominal (or nominalized verb or VP). The dependent NP can also be represented by a situational anaphor (a $3 \mathrm{SG}$ pronominal form) or as a null pronoun if the event is recoverable from the context. Table 3 provides a summary of the various phasal aspect (sub-) constructions in Ewe with their lexical and structural fillers. 
Table 3: Phasal aspect constructions

\begin{tabular}{|c|c|c|c|}
\hline Aspectual Phase & Operator & Event expression & Postposition \\
\hline \multirow[t]{5}{*}{ Inceptive } & $\begin{array}{l}d z e \text { 'become.contacted' } \\
{[\text { Verb] }}\end{array}$ & noun (phrase) & $\begin{array}{l}d z \hat{i} \text { 'upper.surface, } \\
\text { top' }\end{array}$ \\
\hline & $\begin{array}{l}\text { dze 'become.contacted' } \\
\text { [Verb] }\end{array}$ & noun (phrase)/gerund & gəme 'under, bottom' \\
\hline & $\begin{array}{l}\text { tó 'bring.into.vogue' } \\
\text { [Verb] }\end{array}$ & noun (phrase) & gəme 'under, bottom' \\
\hline & $\begin{array}{l}\text { lé 'hold, catch' } \\
\text { [Verb] }\end{array}$ & noun (phrase) & $m e$ 'containing.region' \\
\hline & $\begin{array}{l}\text { dé asî̀ 'put hand' } \\
\text { [Verb Noun] }\end{array}$ & gerund & $m e$ 'containing.region' \\
\hline Durative & $\begin{array}{l}\text { le 'be.at:PRES' } \\
\text { no 'be.at:NPRES' } \\
\text { [Verb] }\end{array}$ & noun (phrase)/gerund & $\begin{array}{l}d z \hat{\imath} \text { 'upper.surface, } \\
\text { top' }\end{array}$ \\
\hline Continuative & $\begin{array}{l}y i \text { 'go' } \\
{[\text { Verb] }}\end{array}$ & noun (phrase)/gerund & $\begin{array}{l}d z \hat{\imath} \text { 'upper.surface, } \\
\text { top' }\end{array}$ \\
\hline Egressive & $\begin{array}{l}\text { wú 'exceed, surpass' } \\
\text { [Verb] }\end{array}$ & noun (phrase)/gerund & $\begin{array}{l}n u \text { 'mouth, entrance, } \\
\text { end-point' }\end{array}$ \\
\hline
\end{tabular}

The forms specified for the constructions-the verbs and the postpositionsespecially those for the inceptive, continuative and egressive can serve as input to various morphological processes, as shown for gerund nominalization in (78).

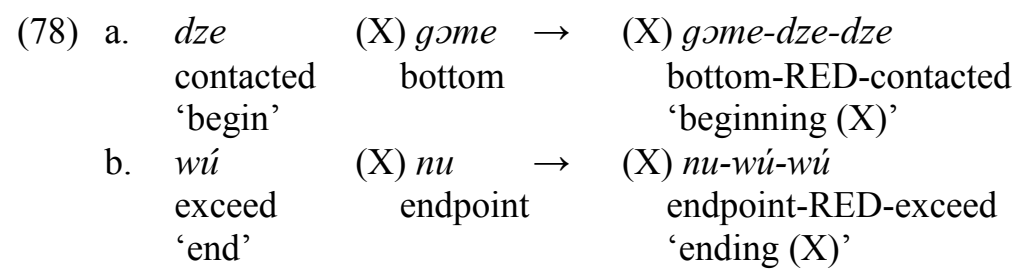

This indicates that the verbs together with the postpositions co-lexicalise the aspectual meaning.

\subsection{Inceptive aspect constructions}

As is evident from Table 3, the verbs involved in the inceptive constructions are roughly speaking "contact" verbs. The semantics of the postpositions which head the event phrases are instructive: the major ones are gome 'under, bottom' and $m e$ 'containing region'. The combination of the verbs and the postpositions 
literally generate underlying schemas of the inceptive constructions which can be stated as: 'make contact with the bottom/containing region of a situation'.

\subsubsection{Constructions involving the verb dze}

There are two constructions involving the verb $d z e$ 'become.contacted': the major one takes the postpositional phrase event complement headed by the postposition gome 'under, bottom'. The minor construction takes $d z i$ 'upper.surface, top' as head of the event phrase postpositional phrase. The event expression in the former, i.e. the dependent constituent of the postposition, can be a noun such as agbe 'life', (see 79b) suku 'school' (80a) or a noun (phrase), as in $(79 \mathrm{a})$ or a gerund nominalization.
a. éye wò-dze
é-fé
nya-wó gome álé...
and 3SG-contacted 3SG-POSS word-PL bottom thus
'and she began her words like this' (Hlomatsi 1995: [2863])
b. ame ádé-wó dze-a agbe gome nyuie
person INDEF-PL contacted-HAB life bottom well
gaké $n u$-wú-wú vá gblée-ná
but endpoint-RED-exceed VENT spoil-HAB
'some people begin life well but the end gets destroyed' (Hlomatsi 1995: [154])

That $d z e$ 'become.contacted' is a bona fide verb in these constructions is evidenced by the fact that it can take the habitual as in (79b). In addition, it also occurs as a verb in a serial verb construction as in $(80 \mathrm{a}, \mathrm{b})$. In (80a) it occurs as head of the initial VP and in (80b) it functions as head of the second VP.
a. deko wó-dze
suku gome yi-na
sế̃́
only 3PL-contacted school bottom go-HAB a.little
'They only just started schooling moving on a little.' (Hlomatsi 1995 [2609])
b. wó-tsó nonome má dze mîá-wó hã nyi-nyi
3PL-take manner DIST contacted 1PL-PL also RED-raise
gome
bottom
'With that same manner they began raising us also' (Hlomatsi 1995 [2789])

As the examples so far illustrate, the dze X gome construction is used to signal the start (beyond the preparatory stage) of a situation. It implies that the situation has temporal extent beyond the initial stage and that it is going to be 
carried through various temporal phases or become a habit, as in the case of starting school, for example.

The $d z e X d z \hat{\imath}$ construction is different from the $d z e X$ gome construction in a number of respects. First there is the formal difference in relation to the different postpositions and also the fact that the dependent constituent in the postpositional phrase in the $d z e X d z \hat{\imath}$ construction can only be a noun and not a gerund. The event expression in the $d z$ X $X$ gme construction can be either a noun or a gerund. Second, the $d z e X d z \hat{i}$ construction, unlike the dze X gome construction, can be used and interpreted literally as the referent of the subject argument "made contact with the surface of X". Third, for the inceptive reading of the $d z e X d z \hat{\imath}$ construction, the dependent constituent nominal in the postpositional phrase typically refers to a place (a location) rather than to an event. All the instantiations of the construction that I have found in a corpus study have a noun that relates to mó 'road, way'. It seems that the construction is used to signal that the referent of the subject argument sets off on a way (to somewhere), a journey so to speak. Consider these examples:
a. wó-dze
afé-mó $\quad d z \hat{\imath}$
3PL-contacted home-road surface
'[They packed his baggage into the vehicle and] they set off for home.' (Hlomatis 1995 [2280])
b. mie-bu-i wò-de ná mi háfi
2PL-think-3SG 3SG-reach DAT 2PL before
dze mó gáa sia dzî kplolá ma.ns.me-e contacted road big PROX surface leader without-PRED a leader.' (Fiawoo 1105) 'You thought it through before you set off on this big road without

There is a reduced form of the construction where the object complement of the verb $d z e$ 'contacted' is just a locative NP without the postposition $d z \hat{\imath}$ 'upper.surface'. Both forms can be used interchangeably. In fact, the postposition can be left out in the sentences in (81) without any appreciable difference in meaning. An example of the reduced construction is given in (82).

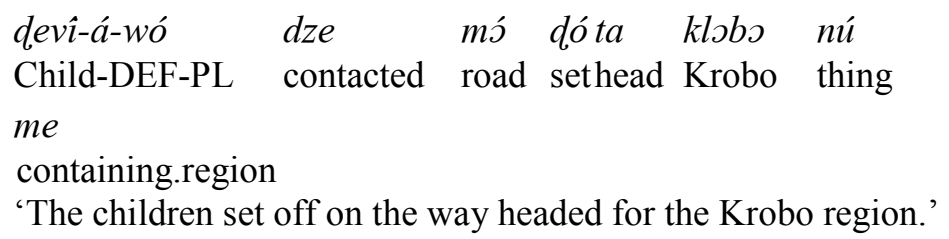

The $d z e X d z \hat{\imath}$ structure does not always have an aspectual interpretation, as noted earlier. In one use, where the subject function is filled by an event referring expression, the expression signals that the event is successful. The one for 
whose benefit such an event is successful is coded as the object of the dative preposition, as the sentence in (83) shows.

$$
\begin{aligned}
& \text { do-wo-wo dze é-dzî ná wó } \\
& \text { work-RED-do contacted 3SG-upper.surface DAT 3PL } \\
& \text { 'Work was successful for them.' (Hlomatsi } 1995 \text { [342]) }
\end{aligned}
$$

Typically the dependent constituent of the postposition in such structures tends to be a situational anaphor or a null pronoun.

The distinguishing feature of the aspectual interpretation of this construction is that the dependent constituent of the postposition is filled by a locative nominal. Another filler of the dependent constituent that yields an inceptive aspectual interpretation is an event referring expression as in (84) below.

$$
\begin{array}{lll}
\text { wó-dze } \quad d o-a & d z \hat{\imath} \\
\text { 3PL-contacted } & \text { work-DEF } & \text { upper.surface } \\
\text { 'They started the work' }
\end{array}
$$

\subsubsection{The tó $\mathbf{X}$ gome construction}

The tó $X$ gome construction is a dialect variant of the dze X gome structure. The verb tó 'bring into vogue' has an inceptive feature lexicalised in it. Hence its use in an inceptive aspect construction is well motivated. As far as I can determine, the event expression is realised as a noun (as opposed to a gerund). An example is given in (85).

$$
\begin{aligned}
& \text { éya-é tó nú-á gome } \\
& \text { 3SG-aFOC bring.into.vogue thing-DEF bottom }
\end{aligned}
$$

Lit: 'HE brought the thing into vogue', i.e. 'HE started the thing'

\subsubsection{The lé X me construction}

The lé $X$ me construction is also used to signal the start of a situation. The verb $l e$ 'hold, catch' takes as its complement a postpositional phrase headed by me 'containing.region' and the dependent constituent of the postposition is an event denoting action nominal such as $a v \check{l}$ 'cry', $d u$ 'race' or $\gamma l \hat{l}$ 'shout', as illustrated in (86).

$$
\begin{aligned}
& \text { nyónu-a lé avi / ylì me } \\
& \text { woman-DEF hold cry shout containing.region } \\
& \text { 'The woman started to cry/shout' }
\end{aligned}
$$

Interestingly, nominals referring to more durative events like suku 'school' or agble 'farm' do not participate in this construction as the unacceptability of the sentences in (87) shows. 


$$
\begin{aligned}
& \text { ?? é-lé agble / suku me } \\
& \text { 3SG-hold farm school containing region } \\
& \text { 'She started farming/schooling' }
\end{aligned}
$$

The HOLD verb is a source of grammaticalization of aspectual meanings like the progressive crosslinguistically. It is therefore not strange that a construction involving the verb can be specialised for the expression of inceptive meaning. A structure with the verb HOLD as the predicate where it takes a noun phrase complement as opposed to a postpositional phrase also gets an inceptive interpretation. This structure is like the reduced $d z e X d z i$ construction that is described in section 7.1.1. In this case too, the noun phrase complement involves the word $m$ ' 'road, way'. Here too, the interpretation is that the referent of the subject argument sets off or takes the road, hence they start on an event, as illustrated in (88).

$$
\begin{aligned}
& \text { é-lé tome-mś / agble-mó } \\
& \text { 3SG-hold river.side-road farm-road } \\
& \text { 'She has set off on the riverside road / the farm road' }
\end{aligned}
$$

The implication of the sentences in (88) is that she is going to the place to engage in the activities normally associated with that place. For instance, if she sets off on the road to the river side then she is either going to draw water or wash clothes or fish in the river.

There is a lexicalised multiverb expression involving the verb lé 'hold' and an event nominal $d u$ 'race' and a second verb tsó 'take' which has the meaning 'start running' (see 89a). This expression is synonymous with an instantiation of the lé $X$ me construction where $\mathrm{X}$ is filled by $d u$ 'race'. Consider these examples:

$$
\begin{aligned}
& \text { a. éye wò-lé du tsó } \\
& \text { and 3SG-hold race take } \\
& \text { 'and he started to run' } \\
& \text { b. éye wò-lé du me } \\
& \text { and 3SG-hold race containing.region } \\
& \text { 'and he started to run' }
\end{aligned}
$$

The inceptive aspect interpretation here as elsewhere derives from the interaction between the semantics of the operator verb, the event referring expression and the postposition.

\subsubsection{The dé así $\boldsymbol{X}$ me construction}

The literal meaning of dé asi $X$ me is 'put hand in X' which conjures up an underlying image of putting one's hands into something to do something with it, 
hence specialised for inceptive meaning. The structure is used to signal the first moment of an unfolding situation. One difference between the dé asi X me construction and the $d z e X$ gome constructions is that the situation whose evolution in time is being described must be expressed as a gerund, i.e. a nominalized VP. For example, even though a stative nominalized form of VP fo $n u$ 'strike mouth' is $n u$ - $f o$ 'talk, speech' and its action nominalization form $n u$ - $f o$ - $f o$ 'talking, speaking' can both fill the $\mathrm{X}$ slot in the $d z e X$ gome construction, as in dze nufo/ nu-fo-fo gome 'begin (a) talk, speech/ talking, speaking', it is only the action nominalization form that is acceptable in the dé asi $X$ me construction, as in (90).

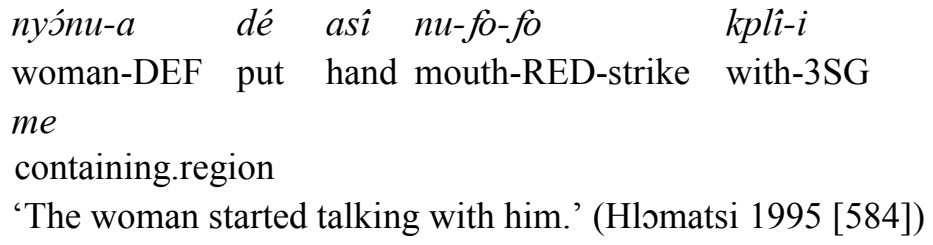

This restriction pre-empts the dé así X me structure from being 'physically' interpreted as putting one's hands into some object. Because such an interpretation is available if the $\mathrm{X}$ slot is filled by a concrete object referring NP such as $t s i$ 'water' as in dé asi tsi me 'put hand in water'.

Another difference between the dé asi X me and the dze X gome constructions is that the latter implies that the situation would develop through other temporal phases. The former, by contrast, does not have such an inference associated with it, it focuses on the initial starting stage of a specific situation.

The dé asi $X$ me construction can be seen as a specialisation of a three place construction involving the verb dé 'put' in which the THEME or first object is lexically filled by asi 'hand' and the GOAL or LOCATIVE complement filled by a postpositional phrase whose head is filled in by me 'containing.region'. The verb dé 'put' in this construction can be marked for the habitual, as in (91a) and it can take preverbs, as in (91b).
a. sélõm vá dé asî ygo-yi-yi me name VENT put hand front-RED-go containing.region 'Selom eventually started making progress.' (Hlomatsi 1995 [1883])
b. éye wó-dé-á asî mónu-dî-dî me and 3PL-put-HAB hand way-RED-seek containing.region 'and they start looking for ways (to obtain riches).' (Hlomatsi 1995[2898])


To sum up, Ewe has a number of constructions which characterise the preparatory and first temporal segment of situations. They are specialisations of the use of contact verbs with their complements.

\subsection{The durative aspect construction}

The durative aspect construction has the form $l e \sim n \supset X d z i$ 'be.at $\mathrm{X}$ upper.surface'. It is based on a specialisation of the basic locative construction with the postposition specified as $d z i$ 'upper.surface, top' (see Ameka and Essegbey 2006). The operator verb is the suppletive locative verb set le 'be.at:PRES' and $n s$ 'be.at:NPRES'. The complement of the verb is a postpositional phrase whose dependent constituent is a noun, as in (92a) or a gerund, as in (92b), which refers to an event.
a. yoxэme no- $a$
$a v \hat{\imath} \quad d z \hat{\imath}$
name be.at:NPRES-HAB cry upper.surface
nú-ma-du-i
thing-PRIV-eat-PRED
'(For days) Yoxэme keeps crying without eating' (Hlomatsi 1995 [475])

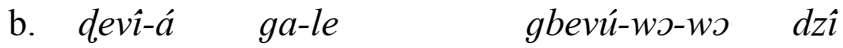
child-DEF REP-be.at:PRES rogue-RED-do upper.surface
'The child still keeps behaving as a rogue'
c. no é-dzî ko
be.at:NPRES:IMP 3SG-upper.surface only
'Just keep doing it'
d. mia-wó-é le (do) dzî
2PL-PL-aFOC be.at:PRES work upper.surface
'You keep working' i.e. Courage!

As is evident from the examples, the non-present form of the verb can be marked for the habitual (92a) and it can also occur in the imperative (92c). Similarly, example (92b) shows that the present form of the verb can occur with preverbs. All these are indications of the verbal status of the operator in the construction. An instantiation of the construction represented in (92d) has been routinised for acknowledging people at work and for urging them to do more work. As indicated in (92d) the dependent constituent of the postposition can be omitted in this routinised expression since it is recoverable from the interactional and cultural context (see Ameka 1991 for a discussion of the routine).

As will become evident in the next section, the formal difference between the durative and the continuative constructions is in the verbs that fill the operator slot. The structural properties as well as the filler for the postposition are 
the same for both constructions. The semantics of the operator verbs provide important clues to the semantics of the constructions. For the durative, the verb is a stative (locative) verb as such it has more stable temporal extent. For the continuative, however, the operator is a motion verb which is dynamic and this is predictive of its contexts of use.

\subsection{The continuative $\boldsymbol{y i} \boldsymbol{X} \boldsymbol{d z i}$ construction}

The continuative phasal aspect is expressed by the motion verb $y i$ 'go' as the operator and its locative complement headed by the postposition $d z i$ 'upper.surface'. The literal meaning then of the expression is 'go on doing something (X)'. The event expression which occurs as the dependent constituent in the postpositional phrase complement can be realised as a gerund, as in (93b), or a noun phrase, as in (93a) or a situational pronoun, as in (93c) or a null pronoun as in (93d).

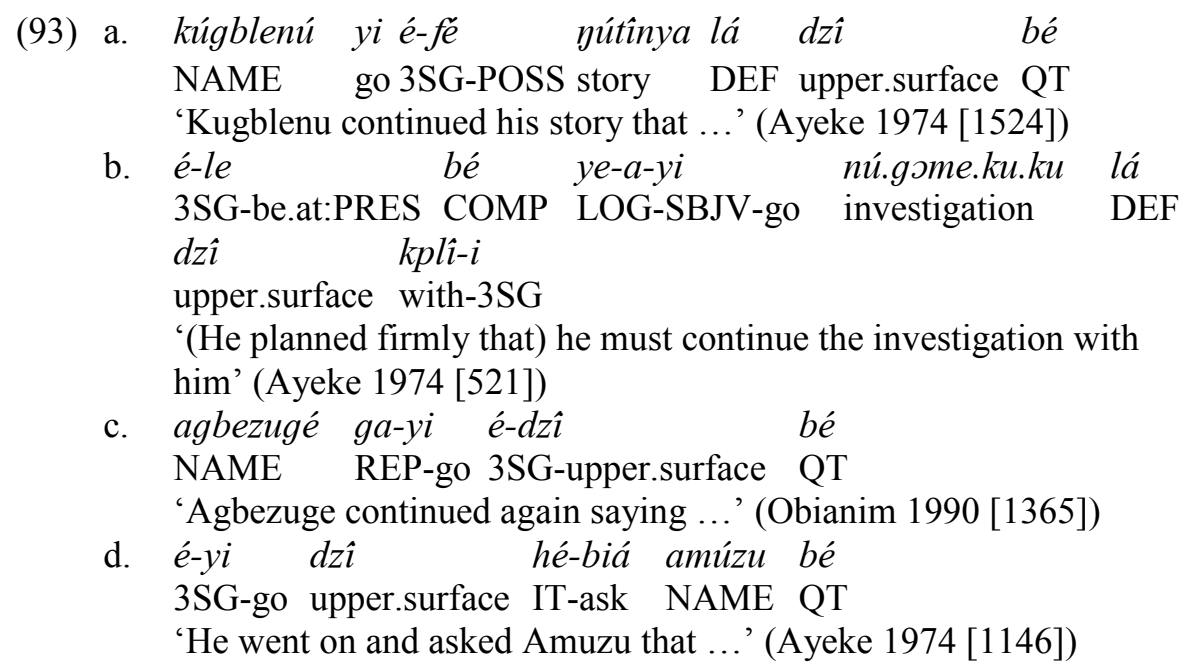

As the examples illustrate, the operator in the construction, $y i$ 'go', can occur with preverb markers such as the subjunctive (93b) and the repetitive (93c). Furthermore, it can head VPs in serial verb constructions, as in (93d) where it heads the first VP in the series. These patterns of collocation show that the operator has the status of a verb in the construction.

The continuative is used to signal that something that is happening should continue. In many cases it is used to indicate that a situation that was no longer occurring for some time has been resumed and will continue for some time. The subtle difference between the continuative and the durative in Ewe is that the latter relates to the situation enduring over the reference time and is equiva- 
lent to 'keep (on)' in English. The former is equivalent to 'go on' and may just be starting at the reference time.

\subsection{The egressive wú $X \boldsymbol{n} \boldsymbol{n}$ construction}

The construction wú $X n u$ literally means 'exceed/surpass the mouth, i.e., the endpoint of $X$ '. It is used to signal that a situation has passed its last moment or temporal segment in its evolution, i.e. it has ended. Like in the other constructions, the dependent constituent of the postposition $n u$ 'mouth, endpoint, extremity' can be a noun (94a) or a gerund (94b) or a pronoun, as in (94e), where it is anaphoric to the subject of the clause which is a referential event expression. The expression representing the event can also be null when it is recoverable from the immediate linguistic context. In (94c) the event denoting expression is null and it is linked to a shared object in an SVC. Similarly, in (94d) the event expression is null, but here is it coreferential with the subject of the clause.

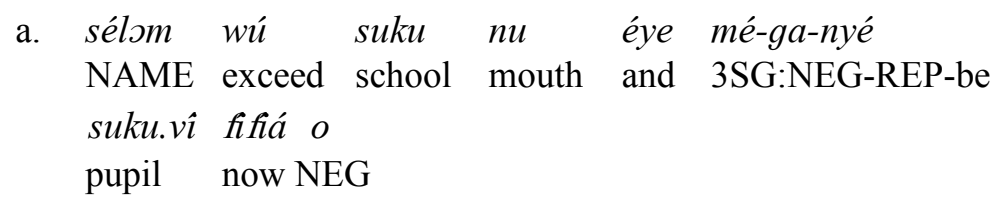

a. sélom wú suku nu éye mé-ga-nyé

NAME exceed school mouth and 3SG:NEG-REP-be suku.vî fifiá o pupil now NEG

'Selom finished school and he is no longer a pupil' (Hlomatsi 1995 [1287])

b. é-si akpéne wú nya sia gbo-gblo nu lá, when NAME exceed word PROX RED-say mouth TP 'when Akpene finished saying this word, (she intoned a song)' (Hlomatsi 1995 [1125])

c. dó vevîe bé na-de-e á-wú put importance COMP 2SG:SUBJV-reach-3SG POT-exceed nu mouth

'Strive so that you will attend it (=medical school) and finish it'(Hlomatsi 1995 [1946])

d. mókeke lá á-wú nu le dzodá si vacation DEF POT-exceed mouth LOC Monday REL gbo-na gbe come-HAB day

'The vacation will end next Monday'

e. ta.kpé.kpé-á wú é-nu meeting-DEF exceed 3SG-mouth

'The meeting ended (when the sun went down)' 
That the verb with its postpositional complement in this construction can occur in an SVC (with shared object) as in (94c) where it is the second VP in the series, as well as the operator being marked for the potential is evidence of the bona fide verbal status of $w u$ ' 'exceed' in this construction.

The difference between the completive, which was discussed in section 6 , and the egressive is that the former focuses on the last part of the nucleus of a situation whereas the latter focuses on the coda, the last moment in the evolution of a situation. Part of the evidence for this comes from the fact the completive can collocate with the egressive to express the idea of imminent completion of the ending of a situation as in (95).

$$
\begin{aligned}
& \text { mié-wú ta.kpé.kpé-á nu vo } \\
& \text { 1PL-exceed meeting-DEF mouth COMPL } \\
& \text { 'We have almost finished the meeting' }
\end{aligned}
$$

While some of the expressions that are dedicated to the expression of phasal aspect in Ewe would seem to follow universal tendencies in the grammaticalization of verbs for these functions, I am not aware of any mention in the literature of the grammaticalization of an exceed verb grammaticalizing to an egressive phasal aspect marker. The motivation is quite transparent especially in combination with an endpoint signifying postposition: the situation has gone beyond its end point. This implies that it has ended. It is this which has become entrenched as the meaning of the construction.

\subsection{Lexicalisation of phasal aspect in verbs}

In the immediately preceding sections, we have described periphrastic constructions in which the phasal aspect meanings derive from the compositional semantics of the operator verb and its postpositional phrase complement. In addition to such constructions, there are also instances where phasal aspect readings are derived from the lexical semantics of verbs, that is, verbs which wear, so to speak, phasal aspect meanings on their sleeves. Such verbs have been called aspectual verbs or aspectualisers (Brrinton 1989). There are other instances where phasal aspect meanings are context-induced interpretations from the lexical semantics of the verb. In this section we briefly outline some of these verbs.

I will start with some aspectual verbs that we have already encountered in the preceding sections and continue with those we have not yet seen:

\subsubsection{The verb tó 'come into vogue'}

We have seen this verb in section 7.1.2 where it occurs in construction with a postpositional phrase headed by the postposition gome 'under' in a two place 
construction. This verb can also occur with a single argument which is an event referring expression to signal the start of a situation. A common expression in which one finds it is: do tó 'famine has started' (literally: stomach come.into.vogue).

\subsubsection{The 'finish' and 'end' verbs}

Two verbs which relate to the terminal viewpoint of situations are $v o$ 'finish' and sé 'end'. We have already seen the grammaticalized forms of these verbs as adverbial aspectuals-the completive $v o$ and the cessative $s e ́$-in section 6 . In spite of having been grammaticalized the verb forms are still used as verbal aspectualisers when they occur in one-place constructions to encode the idea of a situation having been finished or having been terminated (see $96 \mathrm{a}, \mathrm{b}$ )

(96) a. ga vo

Money finish

'The money is finished'

b. nya má né-sé dé afi.ma

word DIST JUSS-end ALL there

'Let that matter end there'

In addition, the verb sé 'end' can also occur in a two place construction and take a locative complement, as in (97).

$$
\begin{array}{lll}
e ́-s e ́ & d u-a & m e \\
\text { 3SG-end village-DEF } & \text { containing region } \\
\text { 'It ended in the village' } &
\end{array}
$$

\subsubsection{The 'stop' verbs}

Two other verbs, which we have not yet seen, also focus on the ending of situations. These are $d z u d z \supset$ 'stop, rest ${ }^{8}$ and tásî 'stop, cease'. These verbs can occur in a one-place or a two-place construction. In other words they are $\mathrm{S}=\mathrm{O}$ ambitransitive verbs. They are largely synonymous. The former is the preferred form in the southern and standard dialects while the latter is more favoured in the inland dialects. The two verbs differ slightly in content as well: tás $\hat{\imath}$ 'stop' relates to the abrupt ending of a situation while $d z u d z$ ' 'stop, rest' implies the ending of a situation as a result of it having reached a natural point where one can stop it, even if just for a short time. Notice that the verb $d z u d z$ ' 'stop, rest' is also used to describe a period of taking rest from some activity. Consider these examples: 

(98) a. tsi-a tásî
water-DEF stop
'The rain stopped'
b. devî-á-wó tási ylî-á dó-dó
child-DEF-PL stop shout-DEF RED-send
'The children stopped shouting'
(99) a. $a v i-a \quad d z u d z \supset$
cry-DEF stop
'The cry stopped.'
b. wó-dzudzo konyî.fa.fa
3PL-stop mourning
'They stopped mourning'

Note that the event denoting expression can be a noun or a gerund, as the examples illustrate.

\subsubsection{Non-aspectual verbs used to express phasal aspect}

In addition to these verbs with an inherent aspectual meaning, there are a handful of verbs which when they collocate with some specific event denoting nominal expression are conventionally interpreted as signalling a temporal phase in the evolution of the situation being characterised in the clause. Three of such verbs are: $k e$ 'open without exerting force', do 'exit, appear, emerge' and $t$ so 'cut'.

The verb ke 'open' in its use as a separation verb is applied to situations involving the opening of body parts like hands, thighs, mouth and eyes. In this usage the body part occurs as an obligatory complement of the verb in a twoplace construction. ${ }^{9}$ The verb can also occur in a one-place construction and when its single argument is realised as a nominal that denotes a state of affairs, it is interpreted as the situation has come to an end. The nouns that typically collocate with the verb yielding such an aspectual interpretation include $t s i$ 'water, rain'. $d s$ 'hunger, famine', ava 'war' and dzre 'quarrel'. For example:

$$
\begin{aligned}
\text { (100) a. } & t s i-\varepsilon \quad k e \\
& \text { water-DEF open } \\
& \text { 'The rain has stopped/cleared' } \\
\text { b. } & d z r e \text { ke } \\
& \text { quarrel open } \\
& \text { 'The quarrel has ended' }
\end{aligned}
$$

Perhaps the motivation for this use and interpretation is that the parts that were involved in the bringing about of the situation have come apart, just as the 
two parts of the body parts come apart when one separates them. Hence the situation no longer holds, i.e. it has ended.

The verb do 'move out from a place thought of a s a container, i.e. exit' as a boundary-crossing verb occurs with a Theme argument in subject function and at least another obligatory constituent whose function is either a locative object or adjunct. The latter is introduced by a spatial preposition (see 101a, b). The verb can also occur in a one-place construction where its single argument is realised as an event denoting nominal, especially meteorological entities and events referring expressions such as $t s i$ 'water, rain', dzinú 'moon, month', $y d s$ 'sun' and te 'yam' when used metonymically to represent the season of new yams. A context-induced interpretation of such structures is the inception of the event/situation (see $101 \mathrm{c}$ )

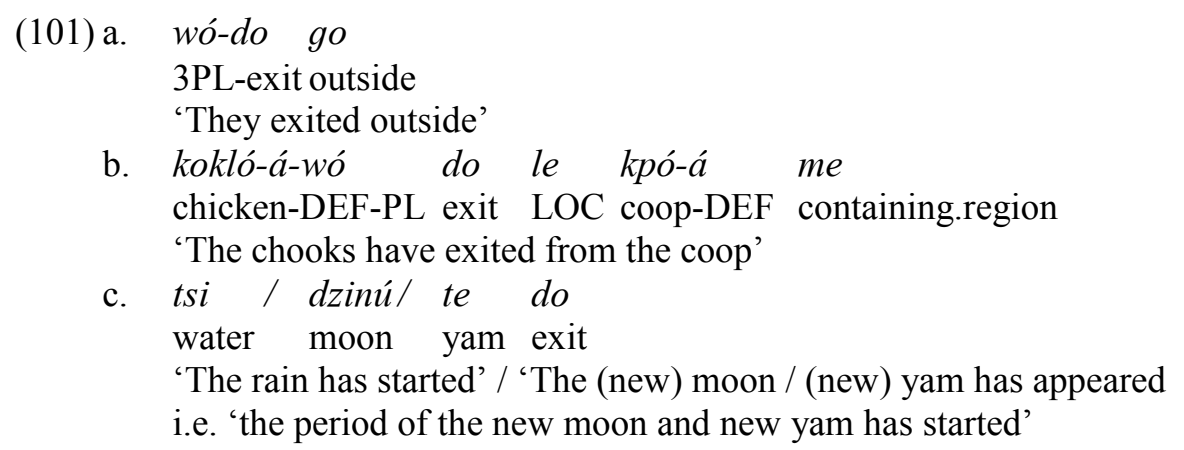

As the translations in (101c) indicate, the structures involving do 'exit' and a situation denoting nominal tend to mark the beginning of an event or a period. It seems as if the beginning is construed as coming about through the movement of the event across a boundary - a kind of fictive boundary - crossing motion. The inceptive reading thus seems to be motivated.

The separation verb tso 'cut' also has a terminative aspect interpretation when it occurs in one place construction in which the single argument involves a situation referring expression. The event denoting nominal can be realised as a noun (phrase) on its own, as in (102b), or as a dependent nominal phrase in a postpositional phrase headed by the postposition $n u$ 'mouth, endpoint' as in (102a),

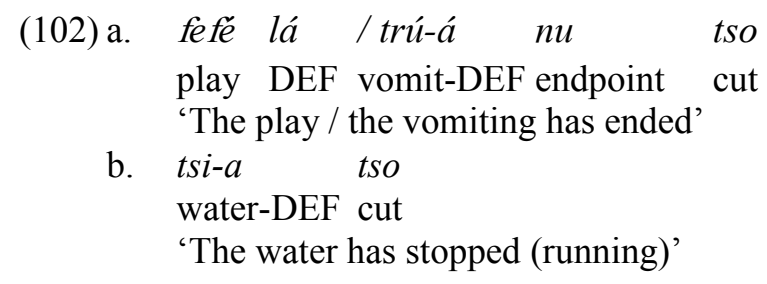


We have already seen the use of the postposition $n u$ 'endpoint' in the coding of the egressive phasal aspect (Section 7.4). It appears the schema underlying the expression involving the verb tso 'cut' is that the endpoint of the event has been severed, which is interpreted as the end of the situation. It does not have to be an abrupt end though, as a separation verb might imply. It just means the occurrence has stopped.

Thus phasal aspect meanings in Ewe are expressed through a number of formal means. They can be expressed using dedicated periphrastic constructions or they may be derived from the lexical semantics of aspectualisers. In addition they may also arise through context-induced readings of specific verbs in collocation with situation referring expressions as we have demonstrated in this last section. We turn now to an emerging periphrastic construction which can be interpreted as proximative aspect in the next section.

\section{The proximative}

The proximative is an aspectual notion that seems "to define a temporal phase located close to the initial boundary of the situation" characterised in the rest of the clause expressing a notion like 'on the verge of V-ing' (Heine 1994:36; see also Heine 1992:339, König 1993:85, Kuteva 1998:127 and Romaine 1999). There seems to be a conventionalised expression for such a meaning in several languages including Maa, Swahili, Zulu as well as Tok Pisin. Furthermore, such expressions involve a form meaning or related to a verb meaning 'want", 'desire', 'love', 'like', 'seek', or 'look for'. Romaine (1999) suggests that the proximative is one of the meanings that Talmy (1985) surmises would not be coded grammatically. However, there is growing evidence that such a meaning is being grammaticalized in several languages such as those mentioned above as well as in Ewe.

The Ewe verb $d \hat{\imath}$ 'want, like, seek, look for' occurs in several syntactic environments which are associated with particular interpretations. It is bivalent. The constituent that fills its subject slot can be animate or inanimate. When it is inanimate and the object slot is filled by an NP, the verb has the interpretation of 'seek'. The same interpretation can also be generated when the subject argument is animate, as the words from a popular song in (103) in which the two clauses mirror each other attest.

$$
\begin{aligned}
& \text { nya mé-dî-á ame o ame-é } \\
& \text { word NEG-want-HAB person NEG person-aFOC } \\
& \text { dî-á nya } \\
& \text { want-HAB word } \\
& \text { 'Trouble does not seek people, PEOPLE look for trouble!' }
\end{aligned}
$$


The constituent that fills the object slot can be an NP $(103,104 \mathrm{a})$ or a complement clause. If it is a complement clause, the verb must be marked for an irrealis category: the subjunctive or the potential, as illustrated in (104b).

$$
\begin{aligned}
& \text { (104) a. áma di ga } \\
& \text { NAME want money } \\
& \text { 'Ama wants money' / 'Ama looked for money' } \\
& \text { b. agbezugé di be ye-a-gbé nyónu-a } \\
& \text { NAME want COMP LOG-SUBJV-refuse woman-DEF } \\
& \text { 'Agbezuge wants to divorce the woman' (Obianim } 1990 \text { [2217]) }
\end{aligned}
$$

In a specific context, the sentence in (104b) can be interpreted as 'Agbezuge was about to divorce the woman'. This is the proximative interpretation of the $d \hat{\imath}$ 'want' + complement construction. This reading is coerced when the subject function in the matrix clause is filled by an NP that is inanimate as in (105). In such contexts the volition sense of the wanting verb is backgrounded and an aspectual interpretation of the construction as a whole is foregrounded.

(105) a. tsi dî bé ye-a-dza

water want COMP LOG-SUBJV-ooze

'Rain wants to fall' i.e. 'it is about to rain'.

b. do di bé ye-a-lé-m

sickness want COMP LOG-SUBJV-catch-1SG

lit: 'Sickness wants to catch me', i.e. 'I am about to become sick'

Thus an instantiation of a WANT complement construction is interpreted as proximative, depending on the fillers. Unlike some of the languages described by Heine and his colleagues such as Maa or Zulu, the verb $d i$ ' 'want' in Ewe has not grammaticalized into a proximative marker. It is the structure as a whole that has the interpretation. In fact, the verb $d \hat{\imath}$ 'want' can be omitted from the sentences containing the be 'QT/COMP' clause and the same patterns of readings are applicable, as the free translations of the sentences in (106) show.

$$
\begin{aligned}
& \text { (106) a. siká bé ye-a-kpś wò } \\
& \text { NAME QT LOG-SUBJV-see 2SG } \\
& \text { 'Sika wants to see you' lit: 'Sika says she would see you' } \\
& \text { b. dzagbeṽ̃e bé ye-a-dé go.me ná-m } \\
& \text { misfortune QT LOG-SUBJV-enter pants DAT-1SG } \\
& \text { 'Misfortune is about to come upon me' } \\
& \text { lit: 'misfortune says it should enter pants for me' }
\end{aligned}
$$

Thus far it would appear that the interpretation of the $d \hat{\imath}$ 'want'+ bé 'QT/COMP' clause construction as desiderative or proximative or both de- 
pends on the animacy of the matrix clause constituent. In contexts where it is inanimate, the interpretation tends to be proximative. In those contexts where it is animate, the interpretation tends to be desiderative or vague. However, in some instantiations of the construction involving constituents in subject function which at first glance might be considered inanimate the interpretation is rather vague. One such context is where the subject of the matrix clause is realized as a possessive NP involving a human (animate possessor) and a possessed part as illustrated in (107).

$$
\begin{aligned}
& \text { É-fé gbe di bé ye-a-de dzi vié } \\
& \text { 3SG-poss voice want COMP LOG-SUBJV-reach sky a.bit } \\
& \text { 'Her voice wanted to rise /was rising a bit' } \\
& \text { 'She wanted to / was about to raise her voice a bit' (Ayeke } 1974 \\
& \text { [1889]) }
\end{aligned}
$$

In this and similar examples, it could be argued that since the NP refers to part of a human, it is not entirely void of animacy, hence the vagueness in interpretation.

Conversely, there are contexts in which the subject of the matrix clause is animate and yet the proximative reading is more focal. This is the case when the dependent clause relates to a property or quality, as in (108).

$$
\begin{array}{lll}
e-d \hat{\imath} & \text { bé } & y e-a-b i \tilde{a} \\
\text { 3SG-want COMP } & \text { LOG-SUBJV-become.macro.red } \\
\text { 'She is almost copper-coloured' }
\end{array}
$$

It would not be unfair to claim that there is a (sub) construction in Ewe which is being specialised for the expression of proximative aspect. Its features can be represented as:

$$
\begin{array}{ll}
\text { The proximative aspect construction } \\
\text { Form: } & \mathrm{NP} \text { [tanimate] }(d \hat{\imath} \text { 'want') be 'COMP/QT' clause [-realis] } \\
\text { Meaning: } & \text { a short time after } \mathrm{t} \text {, the first parts of something can } \\
& \text { happen because of something that is happening at } \mathrm{t} \\
& (\mathrm{t}=\text { reference time })
\end{array}
$$

Because the interpretation of the instantiations of this construction depend to a large extent on the contextual fillers, it is fair to say that its grammaticalization is in progress. One can still derive the interpretations from an interplay between the semantics of the individual items and the context of use. For instance, by virtue of the fact that inanimate entities are not sentient, one does not expect them to be able to have wants, desires and volition (except when they are personified). Such a feature will thus trigger a suppression of the volition feature in the verb, flagging that some other feature be foregrounded. This is 
what can give rise to the proximative interpretation. The same can be said for contexts where the want verb is omitted. In such cases, the quotative could be interpreted as the inanimate entity saying something and the incommensurability of such an interpretation coerces the proximative reading. In fact such matrix verbless sentences with inanimate subjects have a strong preference for the proximative interpretation. Such structures could thus ultimately become the grammaticalized proximative aspectual constructions in the language.

\section{Concluding remark}

In this chapter, I have surveyed the forms used in Ewe to express aspect, mood and modality meanings. By way of conclusion, I want to draw attention to two organising principles of the system. First, I claim that Ewe forces its speakers to express with every utterance a feature related to the realis/irrealis continuum. Second, there is an elaboration in Ewe grammar of the expression of the degree of "imminence" of the realisation of situations. Thus a number of the forms we have described have a meaning component of "something about to happen". The prospective construction has imminent future as one of its primary meanings. A reading of the progressive in certain contexts also involves imminence (see Ameka and Dakubu this volume). Furthermore, the completive marker has an imminent-realisation reading when it collocates with punctual predicates, as well as when it is reduplicated or triplicated (see section 6.1). Moreover, the grammaticalization of a proximative construction is in progress (section 8). A question for future research is whether these features of the system have cognitive salience in discourse practice and whether these are aspects of situations that Ewe speakers attend to in discourse production or in "thinking for speaking".

\section{Endnotes}

${ }^{1}$ This example is taken from a line of girls' puberty love songs. The desiderative sense implicit in the subjunctive is derivable from the continuation of the song:
Má-de wò nè-bé $y i-m a ́-d e-m$
1SG:SUBJV-take2SG
2SG-QT
LOG- $l e=a$
$\begin{array}{llll}\text { Máwúdslá } & d e & g e ́ & n e ̀-l e=a \\ \text { angel } & \text { take } & \text { PROSP } & \text { 2SG-be.at:PRES=Q }\end{array}$
'I wanted to marry you, you say you don't want to marry me, is it an angel who is going to marry you?'

${ }^{2}$ There seems to be an Anlo specific imperative construction which is getting out of use. It involves the suffixing of the form $-\dot{m}$ to the verb (cf. Westermann 1930:76 who says the form is obsolete). For instance, in the TV drama "Tonyeko", when the father, Ganyo, was presenting 
a letter he had received concerning his son Tonyeko to him, he said: $x \supset-m$ ' '2SG:get-IMP' 'Take (it)'. One could speculate that the $m$ form is the distal deictic that is also used in presentational constructions in Anlo. For example, yém '3SG-DISTDEIC' 'That's it' (see Ameka and Essegbey 2006)

${ }^{3}$ The illocutionary meaning of the simple jussive construction can be roughly paraphrased as follows, inspired by The Natural Semantic Metalanguge (NSM) approach of reductive paraphrase (see e.g. Wierzbicka 1988):

$3^{\text {rd }}$ person Subject né VP

I want something to happen

(e.g. I want someone to come into this place, example (31))

I cannot do it

I think someone else can do it (i.e. the referent of the subject)

I know if someone did something it would happen

I say it because I want this person to do it

${ }^{4}$ This counterfactual protasis introducer is identical in form and related, in origin and semantics, to the emphatic question introducer (see Table 2). I have suggested that the two forms come from the predicate focus marker (Ameka 1986 chapter 2). Briefly the scenario for development is that the predicates in the scope of conditional clefts are marked by the predicate focus marker and then these sentences became abridged leaving the predicate focus marker as the introducer of conditions, hypothetical propositions that one wants to have confirmed or disconfirmed. It is conceivable that a full form of a counterfactual conditional is as follows.
né-nyé de me-kpó-e lá á-nyé né me-gblo-e ne
COND-be pFOC 1SG-see-3SG TP IRR-be LINK 1SG-say-3SG DAT:3SG

'If it were that I saw him/her, it would have been that I would have told him/her'

Here the apodosis is also contained within an irrealis clause which is consistent with the use of né. Such forms are still used but the more common are the abridged forms:

${ }^{5}$ Notice that this sentence is ambiguous in English between 'The child is almost mature' and 'The child is very mature'. I am grateful to Alan Duthie for drawing my attention to this ambiguity.

${ }^{6}$ This strategy is employed only in some dialects, most notably the northern dialects. Some other dialects, for instance the Ho dialect, just reduplicate the form. It appears that the Anlo dialect does not make use of any of these.

${ }^{7}$ An utterance containing a proposition modified by the adverbial aspectual kpó can be paraphrased along the lines of reductive paraphrase of the Natural Semantic Metalanguage framework as:

One can know this of some time $t$ (not this time now):

$\mathrm{X}$ (= proposition) happened by $\mathrm{t}$

8 This verb could be historically the intensive form of the verb $d z$ J 'wait'. It would have been derived by reduplication with the vowel in the reduplicative specified as a high counterpart of the stem vowel (see Ameka 1999 for further elaboration).

${ }^{9}$ The lexicalised expression $\eta u$ ke 'eye open' meaning 'it is day break' is the only usage in which the verb occurs intransitively with a body part. This body part term however does not have physical reference. It has a psychological function. 


\section{References}

Aboh, E. O. 1998. From the syntax of Gungbe to the grammar of Gbe. Ph.D thesis, Université de Genève, Geneva

Aboh, E. O. 2004.The morphosyntax of complement head sequences: Clause structure and word order patterns in Kwa. Oxford: Oxford University Press.

Ameka, F. K. 1986. The use and meaning of selected particles in Ewe. MA thesis, Australian National University, Canberra.

Ameka, F. K. 1990a. The grammatical packaging of experiencers in Ewe: a study in the semantics of syntax. Australian Journal of Linguistics 10(2): 139-181.

Ameka, F.K. 1990b. How discourse particles mean: The case of the Ewe "terminal" particles. Journal of African Languages and Linguistics 12(2): 143-170.

Ameka, F. K. 1991. Ewe: its grammatical constructions and illocutionary devices. Ph.D thesis, Australian National University, Canberra.

Ameka, F. K. 1994. Areal conversational routines and cross-cultural communication in a multilingual society. In Intercultural communication, H. Pürschel (ed.), 441-469. Bern: Peter Lang.

Ameka, F. K. 1998. Les particules ènonciatives en ewe. In Les langues d'Afrique Subsaharienne [Faits de langues 10], S. Platiel and R. Kabore (eds), 179-204. Paris: Ophrys

Ameka, F.K. 1999. The typology and semantics of complex nominal duplication in Ewe. Anthropological Linguistics 41: 75-106.

Ameka, F. K. 2003. 'Today is far away': Situational anaphors in multiverb constructions in Ewe. In Studies in the Languages of the Volta Basin 1, M. E. Kropp Dakubu and E. K. Osam (eds), 9-22. Legon, Accra: Department of Linguistics, University of Ghana.

Ameka, F. K. 2006. Ewe serial verb constructions in their grammatical context. In Serial verb constructions: a cross-linguistic typology, A.Y. Aikhenvald and R. M. W. Dixon (eds), 124-143. Oxford: Oxford University Press.

Ameka, F. K. and J. Essegbey 2006. Elements of Ewe grammar of space. In Grammars of space: Explorations in cognitive diversity, S. C. Levinson and D. P Wilkins (eds). Cambridge: Cambridge University Press.

Ameka, F. K. and M. E. Kropp Dakubu this volume. Imperfective aspect constructions: progressive and prospective in Dangme and Ewe.

Ansre, G. 1961. The tonal structure of Ewe. Connecticut: Hartford Seminary Foundation. 
Ansre, G. 1966. The grammatical units of Ewe. Ph.D thesis. University of London.

Ansre, G. 2000. The Ewe language. In A handbook of Eweland. Vol II: The Northern Ewes in Ghana, K. Gavua (ed), 22-47 Accra: Woeli.

Apresjan, J. 2000. Systematic lexicography. Oxford: Oxford University Press. Ayeke, K. 1974. Hlõbiabia [Taking revenge]. Accra: Bureau of Ghana Languages.

Bertinetto, P. M., Ebert, K. et al. 2000. The progressive in Europe. In Tense and aspect in the languages of Europe, Ö. Dahl (ed.), 517-558. Berlin: Mouton.

Bhat, D. N. S. 1999. The prominence of tense, aspect and mood. Amsterdam, John Benjamins.

Bidi Setsoafia, H. K. 1982. Fia tsatsala [The wandering chief]. Accra: Bureau of Ghana Languages.

Bland, S. K. 1988. The present progressive in discourse: grammar versus usage revisited. TESOL Quarterly 22(1): 53-68.

Boadi, L. A. this volume. The verbal affixes in Akan: Time, tense, mood, and aspect.

Botne, R. 1983. On the notion 'inchoative verb' in Kinyarwanda. In Le Kinyarwanda: études linguistiques, F. Jouannet (ed.), 149 - 180. Paris: SELAF.

Brinton, L. J. 1989. The development of English aspectual systems: aspectualizers and post-verbal particles. Cambridge: Cambridge University Press.

Bybee, J. L. 1985. Morphology: a study of the relation between meaning and form. Amsterdam: John Benjamins.

Chisholm, W. S., Milic, L. T. et al.(eds). 1983. Interrogativity. Amsterdam: John Benjamins.

Chung, S. and A. Timberlake. 1985. Tense, aspect and mood. In Language typology and syntactic description, Vol. 3, T.A. Shopen.(ed), 150-201. Cambridge: Cambridge University Press.

Clements, G. N. 1972. The verbal syntax of Ewe. Ph.D thesis. University of London.

Collins, C. 1993. Topics in Ewe syntax. Ph.D thesis. Massachusetts Institute of Technology, Boston.

Comrie, B. 1976. Aspect. Cambridge: Cambridge University Press.

Dahl, Ö. 1985. Tense and aspect systems. Oxford: Basil Blackwell.

Dillon, G. L. 1977. Introduction to contemporary linguistic semantics. Englewood Cliffs N. J.: Prentice Hall

Dixon, R. M. W. 2005. A semantic approach to English grammar. Oxford: Oxford University Press.

Dimmendaal, G. J. 1983. The Turkana language. Dordrecht: Foris. 
Dogoe, E. Y. 1964. Nya zozว. [Know how to walk]. Accra: Bureau of Ghana Languages.

Duthie, A. S. 1988. Ewe. In The languages of Ghana, M.E. Kropp Dakubu (ed.), 91-101. London: Kegan Paul International (for the International African Institute).

Duthie, A. S. 1996. Introducing Ewe linguistic patterns. Accra: Ghana Universities Press.

Dzameshie, A. K. 1998. Structures of coordination in Ewe. Journal of West African Languages 27(1): 71-82

Essegbey, J.A.B.K. 1999. Inherent complement verbs revisited: towards an understanding of argument structure in Ewe. Ph.D thesis, Leiden University.

Essegbey, J.A.B.K. 2004. Auxiliaries in serialising languages: on COME and GO verbs in Sranan and Ewe. Lingua 114(4): 473-494.

Essegbey J. this volume. The potential in Ewe.

Fiawoo, F. K. 1990. Toks Atõlia [The Ffth Landing Stage]. Accra, Sedco.

Foley, W. A. 1986. The Papuan languages of New Guinea. Cambridge: Cambridge University Press.

Freed, A. 1979. The semantics of English aspectual complementation. Dordrecht: D. Reidel.

Gadzekpo B. K. 1982. Ewots ku, edula li [The creator is dead, the consumer is there]. Accra: Waterville.

Heine, B. 1992. Grammaticalization chains. Studies in Language 16(2): 335368.

Heine, B. 1994. The genesis of aspect in African languages: the proximative. BLS 20: 35-46.

Heine, B., U. Claudi and F. Hunnemeyer. 1991. Grammaticalization: a conceptual framework. Chicago: The University of Chicago Press.

Heine, B. and M. Reh. 1984. Grammaticalisation and reanalysis in Arican languages. Hamburg: Helmut Buske.

Hlomatsi, Y. 1994. Agbe nye nusi newre [Life is what you make it]. Accra: Bureau of Ghana Languages.

Johnson, M. 1981. A unified temporal theory of tense and aspect. In Syntax and Semantics 14 Tense and aspect, P. J. Tadeschi and A. Zeaenen (eds), 145-176. New York: Academic Press.

Keleve, M. A. 2002. On please in English in Ghana. In New directions in Ghanaian linguistics, F. K. Ameka and E. K. Osam (eds), 321-338. Accra: Black Mask.

König, C. 1993. Aspekt im Maa. Köln: Institut für Afrikanistik, Universität zu Köln.

Kuteva, T. 1998. On identifying an evasive gram: action narrowly averted. Studies in Language 22: 113-161. 
Lefebvre, C. and A.-M. Brousseau. 2002. A grammar of Fongbe. Berlin: Mouton.

Lord, C. 1993. Historical change in serial verb constructions. Amsterdam: John Benjamins.

Mourelatos, P. 1981. Events, processes and states. In Syntax and Semantics 14 Tense and aspect, P. J. Tadeschi and A. Zeaenen (eds), 191-212. New York: Academic Press.

Obianim, S. J. 1990. Agbezuge. Accra: Sedco.

Osam, E. K. 2002. The ingressive in Akan: a reconsideration. In New directions in Ghanaian linguistics, F. K. Ameka and E. K. Osam (eds), 113126. Accra: Black Mask.

Payne, T. 1997. Describing morphosyntax. Cambridge: Cambridge University Press.

Pazzi, R. 1970. Cours d'initiation. Lome: Mission Catholique.

Romaine, S. 1999. The grammaticalization of the proximative in Tok Pisin. Language 75(2): 322-346.

Talmy, L. 1985. Lexicalisation patterns. In Language typology and syntactic description Vol 3, T.A Shopen (ed), 57-149. Cambridge: Cambridge University Press.

Traugott, E. C. 1988. Pragmatic strengthening and grammaticalization. BLS 14: 406-416.

Van Valin Jr., R. and La Polla R. 1997. Syntax. Cambridge: Cambridge University Press.

Verstraete, J-C. 2002. Interpersonal grammar and clause combining in English. $\mathrm{Ph} . \mathrm{D}$ thesis, Katholieke Universiteit Leuven

Vlach, F. 1981. The semantics of the progressive. In Syntax and Semantics 14 Tense and aspect, P. J. Tadeschi and A. Zeaenen (eds), 271-292. New York: Academic Press.

Warburton, I. P. e. al. 1968. Ewe basic course. Bloomington: Indiana University Linguistics Club.

Welmers, W. E. 1973. African language structures. Berkeley: University of California Press.

Westermann, D. 1930. A study of the Ewe language. Oxford: Oxford University Press.

Whorf, B. L. 1956. Language, thought and reality. J. Carroll. (ed) Cambridge, Massachusetts: MIT Press.

Wierzbicka, A. 1988. The semantics of grammar. Amsterdam: John Benjamin. 